\title{
THE TOPIC OF HEALTH IN THE LETTERS OF GRAND DUKE VYTAUTAS OF LITHUANIA AND HIS CONTEMPORARIES ${ }^{1}$
}

\author{
Rūta Čapaitè
}

\begin{abstract}
The paper discusses information relating to health matters in the letters of Grand Duke Vytautas and his correspondents. Whose health (the rank of the person) do these letters discuss and why were they written? What news and in what form were they submitted (e.g. how were diseases or symptoms described)? Do the letters have information directly related to medical treatment? The information in the letters is supplemented by data from the expenditure books of the treasurer of the Teutonic Order, and chronicle accounts.
\end{abstract}

In the late Middle Ages, letters were not only a means of doing business, but also a form of private communication. This was determined not only by the abundance of types of letters, grouped by function, addressees and addressors ${ }^{2}$, but also by the variety of

${ }^{1}$ This topic was analysed in an article in the Polish language published in 2013: R. Čapaite, 'Sprawy zdrowia i chorób w listach Witolda i jego korespondentów', Kultura Europy Środkowej, t. XVI: Zdrowie i choroba. Wpływ jakości życia na kulture w Europie Środkowej (Katowice-Zabrze, 2013), pp. 36-61. Some statements and interpretations of facts in the sources have been revised or corrected, and the article is supplemented with new data and considerations. The author wishes to thank V. Gerulaitiene and Prof. A. Holvock for their help translating late-medieval German sources.

${ }^{2}$ In the Polish version, one of the most important criteria for grouping letters, i.e. by addressee and addressor, was not mentioned. Schlesisch-böhmische Briefmuster aus der Wende des vierzehnten Jahrhuntert, 'Vom Mittelalter zur Reformation', 5, hrsg. G. Bebermeyers (Berlin, 1926), pp. 3, 4, 12, 20, 22, 24-25, 28-29, 38-41, 45, 132-135, 147, 149, 153-155, 160, 162, also the supplements Lateinisch-deutsche Briefmuster für Laien, pp. 4-75, Lateinisch Briefmuster für Scholaren i Kleriker, pp. 85-113; K. Dülfer, 'Urkunden, Akten und Schreiben im Mittelalter und Neuzeit. Studien zum Formproblem', Archivalische Zeitschrift, Bd. 53 (1957), pp. 15-17; H.-P. Lachmann, 'Deutschordensbriefe aus dem frühen 14. Jahrhundert', Archiv für Diplomatik. Schriftgeschichte, Siegel- und Wappenkunde, 27 (1977), pp. 383-386; H. Wenzel, Hören und Sehen, Schrift und Bild: Kultur und Gedächtnis im Mittelalter (Munich, 1995), pp. 196, 254-256, 258-262, 264, 266, 287-288, 295; H.-D. Heimann, 'Mittelalterliches Briefwesen und moderne Schreibmedienkultur. Praxis und Tagungsthematik', Kommunikationspraxis und Korrespondenzwesen im 
topics discussed in the letters. Letters devoted to mixed themes, in which several questions were considered, became more frequent. ${ }^{3}$ In the correspondence of Grand Duke Vytautas his addressees and addressors in addition to the prevailing political realities, various matters relating to health (e.g. illness, recovery, searching for doctors) sometimes appear. Historians have drawn attention to this when examining the personal, informal relationships between the Grand Duke of Lithuania and the Lithuanian nobility and officials of the Teutonic Order, ${ }^{4}$ in discussing the letter not only as a medium in business affairs, but also as a private means of communication in the everyday life of grand duke Vytautas, ${ }^{5}$ in analysing the everyday life of the Grand Duke of Lithuania and Lithuania's political elite in the Latin-language communicative space ${ }^{6}$ of Europe's elite at that time, and so on. Nevertheless, the news on health issues in the let-

Mittelalter und in der Renaissance, hrsg. H.-D. Heimanned, I. Hlaváček (Paderborn-Munich, Vienna, Zurich, 1998), pp. 10-11, 13; P.-J. Heinig, 'Der König im Brief', ibid., pp. 32-35; H. Boockmann, 'Die Briefe des Deutschordensmeisters', Kommunikationspraxis..., pp. 108-109; W. Rösener, 'Fehdebrief und Fehdewesen. Formen der Kommunikation beim Adel im späteren Mittelalter', ibid., pp. 96-97, 100-101; M. Bláhova, 'Korrespondenz als Quelle der mittelalterlichen Zeitgeschichtsschreibung', ibid., pp. 180-181, 183-186; M. Glauert, 'Schreiben auf der Marienburg. Anmerkungen zur nichturkundlichen Schriftlichkeit in der zentralen Kanzlei des Deutschen Ordens im 14. Jahrhundert', Kancelarie krzyżackie. Stan badań i perspektywy badacze. Materiaty z międzynarodowej konferencji naukowej Malbork 18-19 X 2001, ed. J. Trupinda (Malbork, 2002), pp. 90-105.

${ }^{3}$ Glauert, 'Schreiben auf der Marienburg', pp. 90-105; Boockmann, Die Briefe, p. 109; R. Čapaitè, 'Vytauto laiškai kaip viduramžių epistolinio žanro pavyzdys', Senoji Lietuvos literatūra, kn. 4: Metraščiai ir kunigaikščiu laiškai (Vilnius 1996), pp. 53-55.

${ }^{4}$ R. Petrauskas, 'Tolima bičiulyste: asmeniniai Vokiečių ordino pareigūnų ir Lietuvos valdovų santykiai', Kryžiaus karu epocha Baltijos regiono tautu istorinejje sqmonèje, ed. R.R. Trimonienè, R. Jurgaitis (Šiauliai, 2007), pp. 206, 217; Idem, 'Der Frieden im Zeitalter des Krieges. Formen friedlicher Kommunikation zwischen dem Deutschen Orden und dem Großfürstentum Litauen zum Begin des 15. Jahrhunderts', Annaberger Annalen, 2004, no. 12, p. 34.

${ }^{5}$ R. Čapaite, 'List jako narzędzie komunikacji wielkiego księcia litewskiego Witolda', Studia Źródloznawcze, 50 (2012), pp. 41-56; eadem, 'Vèlyvujjų viduramžiu epistolika - kasdienio gyvenimo atspindys (pagal Lietuvos didžiojo kunigaikščio Vytauto ir jo amžininkų korespondenciją)', Vytautas Didysis ir jo epocha (Trakai, 2010), pp. 48-73; eadem, 'Lietuvos didžiojo kunigaikščio Vytauto kasdienybė pagal jo ir jo amžininkų korespondenciją', Alytaus miesto istorijos fragmentai (Alytus, 2001), pp. 10-27.

${ }^{6}$ Eadem, 'Vèlyvujų viduramžiu epistolika', pp. 56, 59, 62, 65, 71-72; eadem, 'Vytauto laiškai', p. 55; eadem, 'The Everyday Life of Grand Duke Vytautas of Lithuania according to Contemporary Corespondence', Lithuanian Historical Studies, 8 (2003), pp. 1-27; eadem, 'Lietuvos didžiojo kunigaikščio Vytauto', pp. 15, 25-27. 
ters of Vytautas and his correspondents has not yet been addressed more thoroughly as a separate topic.

This article discusses news relating to health matters found in the correspondence of Grand Duke Vytautas. The following issues are discussed: whose health (the rank of the person), and why were they written? What kind of news and in what form were they submitted (e.g. how are diseases or their symptoms described)? Is there information in the letters directly related to the treatment?

In discussing this subject, we have to note that the former abundant correspondence of Vytautas remains very fragmented. ${ }^{7}$ Researchers analysing forms of communication in the late Middle Ages stress that oral communication was still as important as communication by letter, so it was normal that important or confidential information was passed by word of mouth, through couriers or trustworthy persons. ${ }^{8}$ In this context, we can assume that the Grand Duke of Lithuania and his correspondents often discussed health-related issues (e.g. illness, or the state of health of one person or another, etc) verbally, and passed news through messengers or trustees. There is no doubt that there were also other sources of information that are not mentioned in the letters.

The article was written based on the published epistolary legacy of Grand Duke Vytautas ${ }^{9}$ and the published or unpublished letters

${ }^{7}$ Die Kanzlei des Großfürsten Vitold von Litauen. Dissertation zur Erlangung der philosophischen Doktorwürde an der Universität in Wien eingereicht von Antanas Vasiliauskas. Wien, am 14. Mai 1935, p. 136; Čapaite, 'List jako narzędzie komunikacji', pp. 42-46; eadem, Gotikinis kursyvas Lietuvos didžiojo kunigaikščio Vytauto raštinèje (Vilnius, 2007), pp. 26-32; M. Kosman, 'Kancelaria wielkiego księcia Witolda', Studia Źródłoznawcze, 14 (1969), p. 93; idem, 'Dokumenty wielkiego księcia Witolda', ibid., 16 (1971), pp. 140, 154, 165-167.

${ }^{8}$ Heinig, 'Der König im Brief', pp. 32-33; F.-J. Felten, 'Kommunikation zwischen Kaiser und Kurie unter Ludwig dem Bayern', Kommunikationspraxis, pp. 61, 74, 76-77, 88-89; Boockmann, 'Die Briefe', p. 107; I. Hlaváček, 'Kommunikation der Zentralmacht mit den Reichsuntertanen sowie fremden Mächten unter König Wenzel', Kommunikationspraxis, pp. 22, 29-30; Wenzel, Hören und Sehen, pp. 195-196, 203, 254-267.

${ }^{9}$ A. Prochaska, Codex epistolaris Vitoldi magni ducis Lithuaniae (1376-1430). Monumenta medii aevi historica. Res gestas Poloniae illustrantia [further: CEV] (Krakow, 1882); A. Lewicki, Codex epistolaris saeculi decimi quinti, t. II, Monumenta medii aevi historica. Res gestas Poloniae illustrantia [further: CEXV], T. XII (Cracow, 1891); Liv-, Esth- und Curländisches Urkundenbuch nebs Regesten [further: $L U B$ ], Bd. 5, Heft 1 (1414-1423), ed. F.G. v. Bunge (Reval 1862); Codex 
of his correspondents. ${ }^{10}$ News related to health matters found in the letters is further supplemented by the expenditure books of the treasurer of the Teutonic Order, ${ }^{11}$ the court accounts of King Jogaila of Poland ${ }^{12}$ and chronicle accounts. ${ }^{13}$

Not much was written about the theme of health in the letters of the Grand Duke of Lithuania, his addressees and addressors. There is information about their health and that of their immediate circle, ${ }^{14}$ rulers and high-ranking officials, ${ }^{15}$ and the hierarchy of the church. ${ }^{16}$ The data available conditionally by their nature can be divided into direct and indirect. As direct, we attribute the news provided by Vytautas and his correspondents on their own health and of people in their immediate environment, and updates of news about the health of rulers or high-ranking officials. We have in mind

diplomaticus Lithuaniae, ed. E. Raczyński (Wrocław, 1845); Urkundliche Beiträge zur Geschichte des Hussitenkrieges vom Jahre 1419 AN., I: Von den Jahren 1419 1428, ed. F. Palacký [further: Palacký I] (Prague, 1873); Urkundliche Beiträge zur Geschichte des Hussitenkrieges in den Jahren, Bd. II: 1419-1436, ed. F. Palacký [further: Palacký II] (Prague, 1873); Liber cancellariae Stanislai Ciołek. Ein Formelbuch der polnischen Königskanzlei aus der Zeit der husitischen Bewegung, J. Caro (Vienna, 1871), [Archiv für österreichische Geschichte, T. 45, (II Hälfte) besonders gedruckt. Liber cancellariae].

10 Geheimes Staatsarchiv Preusischer Kulturbesitz [further: GStAPK], Hauptabteilung XX, OBA: No. 928, 929, 4562; also see reference no. 10.

${ }^{11}$ Das Marienburger Tresslerbuch. Der Jahre 1399-1409, Bd. 1, ed. E. Joachim (Königsberg, 1896).

${ }^{12}$ Rachunki dworu króla Władysława Jagietly i królowej Jadwigi z l. 1388-1420, ed. F. Piekosiński (Krakow, 1896).

13 Johanns von Posilge, Officials von Pomesanien, Chronik des Landes Preussen (von 1360 an, forgesetzt bis 1419), Scriptores Rerum Prussicarum [further: SRP], Bd. 3, ed. T. Hirsch, M. Töppen, E. Strehlke (Leipzig, 1866); Geschichten von Wegen eines Bundes von Landen und Steten. Wider den Orden unser lieben Frawen und die Bruder desselben Ordens im Lande zu Prussen geschehen, SRP, Bd. 4 (Leipzig, 1870); Historia brevis magistrorum ordinis Theutonici generalium, ed. M. Töppen, SRP, Bd. 4; Ioannis Długossii seu Longini canonici Cracoviensis, Historiae Polonicae, Libri XIII, ad veterrimorum librorum manuscriptorum fidem recensutt, variis lectionibus annotationibusque, instruxit Ignatius Żegota Pauli, cura et impressis Alexandri Przezdziecki, tomus IV, libri XI. XII. (Krakow, 1877).

14 GStAPK, OBA no. 4562; $C E V$, no. 326 , p. 120 ; no. 356 , p. 139 ; no. 362 , p. 143 ; no. 1213 , pp. $713-714$; no. 1216 , p. 716 ; no. 1270 , p. 759 ; no. 1273 , pp. 761-762; no. 1330, p. 800; Palacký I, no. 397, p. 445; Codex diplomaticus Lithuaniae, no. 9, pp. 324-325.

15 GStAPK, OBA no. 928; CEV , no. 349, p. 133; no. 1217, p. 717 (an annotation to the letter's content); no. 1222, p. 720; no. 1418, p. 907; Palacký I, no. 394, p. 441; no. 404, p. 457; Palacký II, no. 691, p. 157; Liber cancellariae, no. 93, p. 170; Codex diplomaticus Lithuaniae, no. 4, pp. 317-318; no. 7, pp. 321, 322; CEXV, no. 180 , pp. 243-244.

${ }^{16} L U B$, Bd. 5, no. 2522 , pp. 704-705; no. 2523, pp. 706-707. 
that they were writing about events that they themselves witnessed, or about which they were very well acquainted. ${ }^{17}$ For example, the reply by Vytautas to the letter of 14 June 1430 from Jogaila, among various other matters, announced that it was foreseen to send other messengers to the congress of Jogaila and the grand master in Torun, because his (Vytautas') messengers who were to go were sick. ${ }^{18}$

We can obtain indirect data on the topic of health by the reconstruction method. The letters of Vytautas and his correspondents were written according to the epistolography rules of the time, ${ }^{19}$ so that many of them are constructed as if ${ }^{20}$ on the principle of dialogue, i.e. first the statement of the addressor is presented, and then it is answered. ${ }^{21}$ As a result, the letters express inquiries and answers on health, express regret for a disease, or the opposite, rejoice after a recovery, and so on, or reveal former health problems. For example, the fact that Paul von Russdorf was sick in 1428 is revealed in a letter to him from Vytautas on 22 August of that year. The reply of the grand duke to the grand master indicates that the very head of the Order reported the recovery. Vytautas, in turn, rejoiced at his recovery, and wished him long-lasting bliss, happiness and health: Ouch als ir uns schreibet von euwir wolfart und wolmogen etc. das ist uns wol lieb czu horen, und wunschen euch lange selikeit, heil und gesundheit. ${ }^{22}$

17 GStAPK, OBA no. 928 (CEV, no. 367, pp. 147-148 - a detailed annotation to the letter's content); 929; 4562. The article of Čapaite, 'Sprawy zdrowia i chorób', p. 39, footnote no. 15 erroneously indicates that the $C E V$ provides a detailed annotation of the content of the letter, whose signature is GStAPK, OBA no. 929 ; $C E V$, no. 326 , p. 120 ; no. 349 , p. 133 ; no. 356 , p. 139 ; no. 359 , p. 141 ; no. 362 , p. 143 ; no. 1213 , pp. $713-714$; no. 1216 , p. 716 ; no. 1222 , p. 720 ; no. 1270 , p. 759 ; no. 1273 , pp. 761,762 ; no. 1418 , p. 907 ; $L U B$, Bd. 5 , no. 2522 , pp. 704, 705; no. 2577, p. 791; Codex diplomaticus Lithuaniae, no. 4, p. 318; no. 7, pp. 321-322; no. 9, pp. 324, 325; Liber cancellariae, no. 93, p. 170; Palacký I, no. 394, p. 441; no. 397, p. 445; no. 404, p. 457; Palacký II, no. 691, p. 157.

${ }^{18} C E X V$, no. 180 , pp. $243-244$.

19 Čapaite, 'Vytauto laiškai', p. 74.

${ }^{20}$ The Polish article of Čapaite, 'Sprawy zdrowia i chorób', p. 39 claims 'the letters of the grand duke and his correspondents were written according to the rules of epistolography at that time, so many of them are constructed as dialogues'. This statement is not quite correct and requires adjustment. The construction of the narratio in the letters of Vytautas and his correspondents sometimes resembles a dialogue, but it is not a dialogue in the literal sense of the word.

${ }^{21} C E V$, no. 326 , p. 120 ; no. 349 , p. 133 ; no. 1330 , p. 800; Palacký I, no. 404, p. 457; Čapaite, 'Vytauto laiškai', pp. 75, 79; Čapaite, 'List jako narzędzie komunikacji', p. 45.

${ }^{22} C E V$, no. 1330 , p. 800. 
In the correspondence of the grand duke and his addressees and addressors, we can distinguish, according to origin, a few groups of indirect data on the topic of health. First: the addressor is interested in the health of the addressee or another person, because he learned that the latter is or was sick. ${ }^{23}$ Second: the addressor informs the addressee about his own or another person's health, since he (the addressor) had been informed (sometimes he indicated, sometimes not, who did this) that the addressee was interested in it. ${ }^{24}$ Third: we learn about the sickness suffered when the recipient of a letter, replying to the letter, thanks the sender for his expressed regret for his (the addressee's) illness, and in turn describes his own state of health (in this case, it is already direct data ${ }^{25}$ ), expresses sorrow for the addressor's health problems, or welcomes his recovery; ${ }^{26}$ or thanks him for sending a doctor. ${ }^{27}$

It sometimes happens that there is direct and indirect information in the same letter. For example, in the letter of 6 April 1427 to Russdorf, Vytautas, thanking him for his concern about his (Vytautas') illness, and rejoicing that he had improved, also wished the grand master health and all goodness. In the grand duke's letter, it is written:

Ouch als ir uns schreibet, wie das euch unser krankheit leid was, und do ir vornamen habit, das wir uns [u]s unserm kranckheit gebessirt habin, des seit ir fro [ge]wesd, der frontschaft und des gutten willes wir euch czumale annemlich dancken, und des gleich wir gunnen euch gesundheit und alles gutes, dofon wir ofte gerne horen wolden [...]. ${ }^{28}$

From whom the grand master learned that the health of Vytautas had improved remains unclear. Perhaps Vytautas himself informed him about this, or other sources could also have informed the leader of the Order.

Direct and indirect data sometimes allow us to discuss hypothetically how long a person was ill, ${ }^{29}$ or reveal that the topic of the illness had been recorded in other (that perished or disappeared) letters. ${ }^{30}$ It also confirms that depending on circumstances, the Grand

${ }^{23}$ Ibid., no. 349, p. 133; Palacký II, no. 691, p. 157.

${ }^{24}$ CEV , no. 326, p. 120 ; no. 349 , p. 133.

25 Ibid., no. 326 , p. 120 ; no. 1273 , pp. $761,762$.

${ }^{26}$ Ibid.

${ }^{27}$ Ibid., no. 1273 , p. 762 ; no. 1330, p. 800; Palacký I, no. 394, p. 441; no. 404, p. 457.

${ }^{28}$ CEV , no. 1273 , pp. $761-762$.

${ }^{29}$ Ibid., no. 349 , p. 133.

${ }^{30}$ Ibid., no. 326 , p. 120 ; no. 349 , p. 133 ; no. 1330 , p. 800 ; LUB, Bd. 5 , no. 2522 , pp. $704-705$; no. 2577 , p. 791. 
Duke of Lithuania, his addressors and addressees, discussed issues related to health verbally, and passed on news through messengers; if necessary, trusted persons would be deployed. ${ }^{31}$ Our material allows us to declare that there were also other sources of information, sometimes probably deliberately not disclosed in letters, or it did not seem important to indicate them, so at this time they remain undetermined. ${ }^{32}$

Grand Master Konrad von Jungingen alluded to his health status in letters to Vytautas in 1405-1407. ${ }^{33}$ The Grand Duke of Lithuania was also interested in the health of the head of the Order. He would ask officials of the Order (e.g. the marshal of the Order) ${ }^{34}$ about this, and maybe the head himself, ${ }^{35}$ and there were some unnamed sources of information. For example, in a letter of 7 September 1405 to Vytautas, Konrad von Jungingen discussed various political issues, and thanked the latter for his expressed regret for his (the grand master's) illness. The head of the Order began his message of thanks by explaining from whom and how he had learned about the grand duke's great concern for his illness. The marshal of the Order had informed Konrad von Jungingen about it: Ouch hat uns unser marschalk geschrebin, wie im euwer herlichkeit hat geschrebin, das ir von unser crankheit vornomen hett und euch leit were. ${ }^{36}$ We do not have the letters of Vytautas and the marshal (they are destroyed or lost), so it is not known who informed the grand duke about the illness of Konrad von Jungingen. It is not clear whether, in the letter to the marshal, Vytautas indicated from whom or under what circumstances he had learned about the grand master's illness. It is also unknown what the official of the Order replied to Vytautas. The source of information also remains not established in another case. In 1406, Vytautas, knowing that the grand master was again

${ }^{31}$ GStAPK, OBA no. 928 (CEV, no. 367, pp. 147, 148 - a complete annotation of the letter's content); Codex diplomaticus Lithuaniae, no. 9, pp. 324-325; CEV, no. 359 , p. 141 ; no. 1222 , p. 720.

${ }^{32} C E V$, no. 326 , p. 120 ; no. 349 , p. 133 ; Liber cancellariae, no. 93 , p. 170 ; Palacký I, no. 394, p. 441.

${ }^{33} C E V$, no. 326 , p. 120 ; no. 356 , p. 139 ; no. 362 , p. 143 ; no. 392 , p. 168.

${ }^{34}$ Ibid., no. 326, p. 120; no. 349, p. 133.

${ }^{35}$ In Čapaite, 'Sprawy zdrowia i chorób', p. 40. There is a statement to be corrected, allegedly Vytautas himself would ask Konrad von Jungingen about his health. I was unable to find any direct or indirect data confirming this statement.

${ }^{36} C E V$, no. 326, p. 120. Čapaite, 'Sprawy zdrowia i chorób', p. 41, contains typographical errors in the quote: marszalk geschreben should be marschalk geschrebin, geschreben should be hat geschrebin, kranheit should be crankheit. 
seriously ill, asked the marshal of the Order to write to him about how matters were going for the other (the grand master). We do not have the letter of Vytautas (it is destroyed or disappeared), so it is unclear whether he mentioned who had informed him about the illness of Konrad von Jungingen. We learn about the request of Vytautas and the illness of the grand master from the (3 September $1406)^{37}$ reply of the Order's marshal to the grand duke:

Ouch libir herre, so schreibt uns euwer hochwirdikeit, begerende, das wir euch schreiben wie es unserm homeister gee, went ir vornomen hattet, das her vaste krenklich gewest were. ${ }^{38}$

In a multi-topic letter of 12 January 1422 to the grand master, the Livonian master, in addition to a variety of political subjects, also mentioned his illness, and also that he had already written to the head of the Order about it. ${ }^{39}$ The correspondence reveals that in the spring of 1426, and perhaps the summer, King Jogaila of Poland suffered from various health problems. The King of Rome, Sigismund of Luxemburg, in a letter of 18 March 1426 to Jogaila, deplored the lamentable event (casu lugubri) and expressed the hope that with the help of the Lord God his health would return. ${ }^{40}$ Jogaila, in a letter of 22 March 1426 to Russdorf, thanked him for the donated falcons, and mentioned that he was suffering from foot pain. ${ }^{41}$ The poor health status of Jogaila is written about in the 2 May 1426 letter of the Elbing komtur to the grand master. ${ }^{42}$ Sigismund of Luxemburg, in a letter of 15 May 1426 to the cities

37 Ibid. There is a typographical error in the date of the letter of the marshal of the Order. It is written ' $z 3$ września 1406 roku'. Meanwhile the letter is hypothetically dated 3 September [1406]. (See: $C E V$, no. 349, p. 133) or [3 September 1406]. See: Regesta historico-diplomatica Ordinis, no. 883, p. 51. In this article the letter is dated according to Regesta historico-diplomatica Ordinis, i.e. [3 September 1406].

${ }^{38}$ CEV , no. 349, p. 133.

39 ...und sich vorzogen hat so lange umb unsir krankheit willen, mit der wir, als wir euwir gnoden im andern unsirm briefe, mit eime A. gezeichnet, geschreven haben, swerlich bevallen sin gwesen, so das wir nu mit der hulfe Gotis von tage zu tage besserunge hoffen. LUB, Bd. 5, no. 2577, p. 791.

${ }^{40}$ Liber cancellariae. I, no. 93, p. 170; Serenissimo principi salutem et fraterne dileccionis continuum incrementum. Serenissime princips, frater carissime! Audita v. s. valetudine et casu lugubri tanto maiore dolemus amaritudine animi, quando ex sinceritate cordis incolumitatem vestram magno desiderio preoptamus, Sperantes in domino, quod ipse qui percutit et medetur, cito manum porriget sospitatis et dabit cum temptacione prouentum, Palacký I, no. 394, p. 441.

${ }^{41}$ GStAPK, OBA, no. 4562.

${ }^{42}$ Codex diplomaticus Lithuaniae, no. 9, pp. 324-325; CEV, no. 1222, p. 720. 
of Wetterau (addressed to den Burgermeister Reten vnd burgern gemeinlichen den Stete Frankfurt vnd sust aller anderer Stete in der Wederaw), informed about his illness. ${ }^{43}$ The Nuremberg Council in a letter of 7 June to the King of the Romans expressed regret for his illness. ${ }^{44}$ In 1427, both Vytautas and Julijona were sick. The illnesses and recovery of the two are written about in the letters of the grand duke to Russdorf. ${ }^{45}$ As has already been mentioned, Russdorf informed Vytautas about his recovery in $1428 .{ }^{46}$

The subject of the health of high-ranking officials and the Church hierarchy was a relevant topic. The leadership of the Order was interested in the health of one of the most influential nobles, Cupurna, the marshal of Vytautas' court. ${ }^{47}$ In 1407, the envoy of the Order, the Brandenburg komtur Markward von Salzbach, in a hypothetical letter-report dated 27 May (1407) informed the grand marshal of the Order about the deteriorating health of Čupurna. ${ }^{48}$ In the address of the letter, an urgent formula is written directing that the letter should be delivered regardless of the time of day, i.e. day or night, without delay, Deme Ersamen Obirsten marschalke mit wirdicheit

43 Palacký I, no. 397, p. 445; no. 404, p. 457.

44 ... sölliche krankheit haben wir mit betrübten herzen vornemen und ist uns mit ganczen trewen laid, ibid., no. 404, p. 457.

${ }^{45} C E V$, no. 1270 , p. 759 ; no. 1273 , pp. 761-762.

46 Ibid., no. 1330 , p. 800.

${ }^{47}$ Petrauskas, 'Der Frieden im Zeitalter', p. 34; idem, 'Tolima bičiulyste', p. 217.

48 GStAPK, OBA, no. 928 (CEV, no. 367, pp. 147-148 - detailed summary of the contents of the letter); Petrauskas, 'Der Frieden im Zeitalter' (in 2004). Petrauskas dates the letter of the Brandenburg komtur as 1407 and states that it is for the grand master. However, the addressee raises doubts, because the letter is addressed to the highest marshal of the Order Deme Ersamen Obirsten marschalke (GStAPK, OBA no. 928). A. Prochaska dated the letter 27 May [1407] and indicated that it is for the deputy of the master. In: $C E V$, no. 367, pp. 147-148. W. Hubatsch hypothetically dated the letter of the Brandenburg komtur as 27 May 1407, and as its recipient showed the chief marshal of the Order. In: Regest historico-diplomatica Ordinis, no. 928, p. 54. The investigator dates the treatment of Čupurna in the Order in 1407. In a Lithuanian-language version of the mentioned article published in 2007 (Petrauskas, 'Tolima bičiulyste', p. 217) the scholar dates the letter as 1397 and as earlier stated, it is for the grand master. Petrauskas also transfers Čupurna's treatment in the Order to 1397. The scholar did not submit arguments on the basis of which he changed the dating of the Brandenburg komtur's letter and based on what he dates in 1397 the entries of the expenditure books of the Order's treasurer for the costs associated with the treatment of Čupurna in the Order. In the book of the expenditures of the Treasurer of the Order, the costs for the treatment of Čupurna are dated 1407 and 1408. Das Marienburger Tresslerbuch, pp. 430, 504. Later in the article the mentioned letter and the records of the funds for the treatment of the marshal of the court of Vytautas are dated, the letter to 1407, the records to 1407 and 1408 . 
tag und nacht ane Sumen. ${ }^{49}$ The envoy reported that he had been invited for supper by Vytautas, and during it they talked quite a bit about the health of Čupurna; he briefly informed about what had been said. Then he announced other news and court details (e.g. that Vytautas, through Čupurna, was sending a hunting falcon (Gyervalken) to the chief marshal of the Order. According to the komtur, it is truly good, because he himself saw it flying: her ist werlichin gut, went wirn selbin haben gesehen flygen. The chief marshal of the Order, in a letter hypothetically dated May 1407 (more likely it was a letter which only listed forwarded letters), ${ }^{50}$ sent to the Elbing komtur also the letter of Markward von Salzbach. ${ }^{51}$ In 1421, the letters of the Livonian master to the grand master emphasised that the Archbishop of Riga was very ill. ${ }^{52}$ As has already been mentioned, the Grand Duke of Lithuania in 1430 informed both Jogaila and Russdorf, about his sick messengers, the Vilnius palatine Gedgaudas ${ }^{53}$ and the Trakai palatine Jaunius Valmantaitis. ${ }^{54}$ From the letters of Jogaila to the Elbing komtur, and the latter's letter to Paul von Russdorf, we learn about the health problems of Jan Tarnowski, the Palatine of Cracow. ${ }^{55}$

Matters of health were written about for a variety of reasons. In most cases, it was related to current affairs and political realities. ${ }^{56}$ For example, explaining that due to an illness the addressor

49 GStAPK, OBA, no. 928.

50 Čapaite, 'Sprawy zdrowia i chorób', p. 41, in footnote no. 43 there is a typographical error in the date of the Brandenburg komtur's letter. It is written 27 maja 1407 roku. Meanwhile, the letter is hypothetically dated 27 May [1407]. CEV , no. 367, pp. 147-148 or [27 May 1407]; Regesta historico-diplomatica Ordinis, no. 928 , p. 54 .

${ }^{51}$ GStAPK, OBA, no. 929.

${ }^{52}$ LUB, Bd. 5, no. 2522, pp. 704-705; no. 2523, pp. 706-707.

53 Čapaite, 'Sprawy zdrowia i chorób', pp. 44, 50 the name of the Vilnius palatine is given as Gietgud, it should be Gedygold. In sources, the form of the name varies e.g. Gedigold (CEV, no. 1418, p. 907), Gedigolt, Gedegow and others see Petrauskas, Lietuvos diduomenè XIV a. pabaigoje - XV a.: sudètis - struktūravaldžia, p. 231.

${ }^{54} C E V$, no. 1418 , p. 907 ; $C E X V$, no. 180 , pp. 243-244.

55 Codex diplomaticus Lithuaniae, no. 4, p. 318; no. 7, pp. 321-322; no. 9, pp. 324-325.

${ }^{56}$ GStAPK, OBA, no. 928; $C E V$, no. 1222, p. 720; no. 1418, p. 907; LUB, Bd. 5, no. 2522, pp. 704-705; no. 2523, pp. 706-707; CEXV, no. 180, pp. 243-244; Codex diplomaticus Lithuaniae, no. 9, pp. 324-325; Palacký I., no. 397, p. 445. 
or his official could not complete, or in general could not perform, certain duties, work or orders on time. ${ }^{57}$ For example, Konrad von Jungingen, in a letter to Vytautas on 13 December 1406, explained that due to an illness he was late in answering his letter. ${ }^{58}$ Writing about health issues was a sign of good political, and sometimes rather good political and personal, relations with the addressee. ${ }^{59}$ Also, there could be an aim to create such an image. ${ }^{60}$ Requests to send a physician in some area comprise a separate group. ${ }^{61}$

Who reported, to whom, about whose health, and why (e.g. the addressor himself was sick, or was a witness to the illness of another person, etc) determined the nature of news about health in the letters of Vytautas and his addressees. ${ }^{62}$ Current affairs, political nuances, sometimes political or political and personal relations, various circumstances at the time, and other factors, had an influence. An illness, recovery and so on were most often written about in multi-thematic letters. ${ }^{63}$ Rarely was the entire letter devoted to the topic of health. ${ }^{64}$ The available information can be grouped

${ }^{57} C E V$, no. 356 , p. 139 ; no. 1418 , p. 907 ; $L U B$, Bd. 5 , no. 2522 , p. 705 ; no. 2523 , p. 707; Palacký I, no. 397, p. 445; no. 404, p. 457; Palacký II, no. 691, p. 157.

${ }^{58} C E V$, no. 356, p. 139.

${ }^{59}$ Petrauskas, 'Tolima bičiulystè', pp. 206, 217; idem. 'Der Frieden im Zeitalter des Krieges', p. 34.

${ }^{60} C E V$, no. 1270 , p. 759 ; no. 1273 , pp. $761-762$; no. 1330 , p. 800 .

${ }^{61}$ Codex diplomaticus Lithuaniae, no. 4, p. 318; no. 7, pp. 321, 322; no. 9 , pp. 24, 325; CEV, no. 1213, pp. 713-714; no. 1216, p. 716; M. Broda, Lekarze w Państwie Zakonu Krzyżackiego w Prusach w XIV-XV wieku (Krakow, 2013), pp. 64-65, 103-105, 107; Ch. Probst, Der Deutsche Orden, und sein Medizinalwesen in Preußen. Hospital, Firmarie und Arzt bis 1525 (Marburg, 1994), pp. 165-166.

62 GStAPK, OBA, no. 928; $C E V$, no. 349 , p. 133; no. 1213, pp. 713-714; no. 1216 , p. 716 ; no. 1222 , p. 720 ; no. 1273 , pp. $761-762$; no. 1418 , p. 907 ; Codex diplomaticus Lithuaniae, no. 4, pp. 317, 318; no. 7, pp. 321-322; no. 9, pp. 324-325; LUB, Bd. 5, no. 2522, pp. 704-705; no. 2523, pp. 706-707; Liber cancellariae. 1, no. 93 , p. 170; Palacký I, no. 394 , p. 441, no. 397 , p. 445; no. 404, p. 457, Palacký II, no. 691, p. 157.

${ }^{63}$ GStAPK, OBA, nos. 928-929, 4562; $C E V$, no. 349, p. 133; no. 356, p. 139 ; no. 359 , p. 141 ; no. 362 , p. 143 ; no. 1213 , pp. $713-714$; no. 1216 , p. 716 ; no. 1217 , p. 717 ; no. 1222 , p. 720 ; no. 1270 , p. 759 ; no. 1273 , pp. $761-762$; no. 1418 , p. 907; Codex diplomaticus Lithuaniae, no. 4, pp. 317-318; no. 7, pp. 321-322; no. 9, pp. 324-325; $L U B$, Bd. 5, no. 2522, pp. 704-705; no. 2577, p. 791; Liber cancellariae, no. 93, p. 170; Palacký I, no. 394, p. 441; no. 397, p. 445; no. 404, p. 457; Palacký II, no. 691, p. 157.

${ }^{64}$ Codex diplomaticus Lithuaniae, no. 7, pp. 321-322; CEV, no. 1213, pp. 713-714. 
into business, ${ }^{65}$ business-personal ${ }^{66}$ and personal. ${ }^{67}$ The material information is related to political realities and carrying out duties and orders. For example, in a letter to Vytautas on 7 September 1405, the grand master reported that, in accordance with his wish, he had sent a messenger to the people of Novgorod, who had still not returned. Konrad von Jungingen stated that it was not clear why: because of illness or other reasons. ${ }^{68}$ The Livonian master, in a letter of 4 January 1421 to the head of the Order, emphasised the poor state of health and honourable age of the Archbishop of Riga, referring to his possibilities to continue in office. ${ }^{69}$ On 6 January of the same year, in a letter to Michael Küchmeister von Sternberg, the Livonian master returned to the theme of the Archbishop of Riga, emphasizing the need to think about a successor favourable to the Order. ${ }^{70}$ The Elbing komtur, a witness to the illness of the King of Poland, in a letter written in Toruń on 2 May 1426, informed the grand master about the severely deteriorating health of Jogaila, emphasising that his grace (sine gnoden) became very weak in a short time. ${ }^{71}$ In 1426, Sigismund of Luxemburg fell ill during a trip to the Reichstag of the Holy Roman Empire in Nuremberg (Dieta Imperii or Comitium Imperiale). In a letter of 15 May 1426 to the Wetterau cities, the King of the Romans reported his illness, and that because of it he would not be able to participate in the Reichstag. He presented all of this in the context of his journey to the Reichstag. In the letter of the King of the Romans it is written:

So riten wir gen Waradin zu sant Laslaw, als wir vns dahin gelubt hatten, vnd als wir herwider qwamen, do qwamen zu vns Conrad von Bickenbach vnd Friderich vom Stein, der Erczbischoue zu Mentz vnd zu Trier Rete, den wir sagten, das wir In nachuolgen wolten gen Nuremberg, als wir ouch das den kurfursten geschriben

${ }^{65}$ GStAPK, OBA, no. 928 ; $C E V$, no. 349 , p. 133; no. 1222 , p. 720 ; no. 1418 , p. 907. Codex diplomaticus Lithuaniae, no. 9, pp. 324-325; LUB, Bd. 5, no. 2522, pp. 704-705; no. 2523, pp. 706-707; Liber cancellariae, no. 93, p. 170; Palacký I, no. 394, p. 441, no. 397, p. 445; no. 404, p. 457; Palacký II, no. 691, p. 157.

${ }^{66}$ CEV , no. 326, p. 120 ; no. 356 , p. 139; no. 359, p. 141; Codex diplomaticus Lithuaniae, no. 7, pp. 321-322.

${ }^{67} C E V$, no. 1213 , pp. $713-714$; no. 1270 , p. 759 ; no. 1273 , pp. $761-762$.

${ }^{68}$ Der selbe bohte ist noch nicht wider czu uns komen; nicht konnen wir dirfaren, wie is umb in ist, ap her von crankheit adir von andern sachen vorhindert sei. CEV, no. 326, pp. 119-120.

${ }^{69} L U B$, Bd. 5, no. 2522, pp. 704-705; Čapaitè, 'Sprawy zdrowia i chorób', p. 44, the specified date of the letters of the Livonian master to the grand master is stated erroneously. Instead of 1421 it is written 1407.

${ }^{70} L U B$, Bd. 5, no. 2523, pp. 706-707.

${ }^{71}$ Codex diplomaticus Lithuaniae, no. 9, pp. 324-325; CEV, no. 1222, p. 720. 
haben, Also schichten wir vns an den wegk vnd qwamen her zum Tottas, do vielen wir in krankheit mitnamen die sciatica des Ruckes. ${ }^{72}$

The fact that Vytautas, replying to the letter of the King of Poland of 14 June 1430, reported that after the envoys he had appointed earlier to the planned congress of Jogaila and the grand master in Torun fell ill, he was replacing them with others, is linked to the inability to carry out orders and diplomatic etiquette. The letter from Vytautas deals with many topics, the replacement of the envoys is written about at the end of the letter. ${ }^{73}$ In a letter of 20 June 1430 to Russdorf, the Grand Duke of Lithuania, among various current affairs, also reported the replacement of the mentioned envoys after they fell ill. ${ }^{74}$ The information given to Jogaila about the illness of the envoys did not differ essentially from that supplied to the grand master, but had a few more details. Vytautas told Russdorf that he would gladly have sent Gedgaudas, and Jaunius, the palatines of Vilnius and Trakai. But the Vilnius Palatine was sick in his feet (unhealthy feet), and the Palatine of Trakai was also in bad health. In the letter, it is written:

wir hetten gerne den strengen woye[wo]d Gedigold dorczu gesant habin, sunder her ist czumale kranck uff seine beine. Ouch wir hettin gerne den woye[wo]d von Tracken Jawnu[ten] gesandt, und der ist auch sich, und also senden wir nach nochgeschrebene: strenge Rumbold unser landtmarschalk und Peter hauptman von Nowogrodek und Gastolden unsern houffmarschalk und Maldrzick unsern secretarium $[\ldots] .{ }^{75}$

Instead of the sick envoys, Vytautas sent Rumbaudas Valimantaitis (Lithuania's grand marshal), Petras Mangirdaitis (the lord lieutenant of Naugardukas), Jonas Goštautas (the marshal of the sovereign) and his secretary Mikalojus Maldrzyk. ${ }^{76}$

72 Palacký I, no. 397, p. 445.

${ }^{73}$ CEXV, no. 180 , pp. 243-244.

${ }^{74}$ CEV, no. 1418, p. 907.

${ }^{75}$ Ibid.; Čapaite, 'Sprawy zdrowia i chorób', p. 44 contains typographical errors: her hat czumale kranck should be her ist czumale kranck, nach geschrebene should be nach nochgeschrebene, Gastolden unser houffmarschalk und Maldrzik should be Gastolden unsern houffmarschalk und Maldrzick.

76 CEV , no. 1418, p. 907; CEXV, no. 180, pp. 243-244. Petrauskas states that Jaunius was due to be the envoy to the planned congress in Torun of Jogaila and the grand master, at which the issue of the coronation of Vytautas was to be decided; due to other matters he did not travel there. See Petrauskas, Lietuvos diduomene, p. 248. This scholar relies on the letters of Vytautas, and in them the main reason for Jaunius not travelling to the congress is given as his illness. The researcher did not provide any additional information, supported by arguments in other sources, testifying to the great business of the Trakai voivod. 
In information of a subject-personal nature about health, they would also first report on what related to the performance of duties or orders. However, details of a personal nature were inserted into these messages. For example, Konrad von Jungingen, in a letter of 13 December 1406 to Vytautas apologizing that he was late in replying to his letter, wrote that due to illness for a few days he could not prepare a reply. The head of the Order presented a short episode about his health, testifying that he had been quite seriously ill. According to the grand master:

Und geruchet lieber herre nicht vor arg czu nemen, ab eingerlei vorsumpnis an der vorantwertunge ist gescheen, wend di scholt etlicher mase unser ist, wend wir kunden czu stunden durch crankheit wille binnen etlichen tagen die antwert nicht usrichten. ${ }^{77}$

In the news of a personal nature ${ }^{78}$ about health (illness, recovery), they would first tell about important matters for the addressor. Very little news of this nature was found in the correspondence analysed. ${ }^{79}$ In such cases, Vytautas and his addressees provided more personal details associated with feelings. For example, in the letters to Russdorf in 1427, Vytautas not only discussed political issues and news, but also mentioned some details of the improvement in his health, and also mentioned the illness and recovery of Grand Duchess Julijona. ${ }^{80}$

Sometimes the boundary between subject-personal and personal information is very thin, so it is not easy to decide what it is. ${ }^{81}$

Issues of health are presented concisely in the letters analysed. Rarely did the grand duke and his correspondents write more broadly about an illness or recovery. Nevertheless, we can divide the available information on health issues, regardless of its nature (business,

$77 C E V$, no. 356, p. 139. The letter in the publication is dated 1406 , but that is a typographical error.

78 Čapaite, 'Sprawy zdrowia i chorób', p. 45 states 'in the correspondence of a private nature there is information about the state of health (illness or recovery), which was primarily very important to the addresser himself'. This is an inaccurate claim; this was not private correspondence, but only brief items of news on health issues found occasionally in multi-thematic letters.

${ }^{79}$ CEV , no. 362 , p. 143 ; no. 1270 , p. 759 ; no. 1273 , p. 762.

${ }^{80}$ Ibid., no. 1270 , p. 759 ; no. 1273 , p. 762.

81 Ibid., no. 362, s. 143. Čapaitè, 'Sprawy zdrowia i chorób', p. 45 states 'sometimes the boundary between officially-private and private information is so inconspicuous that it is difficult to name the nature of the correspondence'. This claim needs to be adjusted; the nature of the correspondence is clear, ambiguity arises in defining the nature of the news of health issues. 
business-personal, personal) into laconic and extended. ${ }^{82}$ Information is laconic when only one fact is presented, for example, a person was sick, is sick, or the opposite, he recovered. ${ }^{83}$ For example, the marshal of the Order, in response to the question from Vytautas about the health of Konrad von Jungingen, in a letter hypothetically dated 3 September 1406, replied briefly. According to the official, the grand master was a little sick that summer, but now, thanks to the Lord God Almighty, he is perky and completely healthy. In the letter, the marshal of the Order writes:

Gerucht libir herre wissen, das unsir homeister uff dese czit von der almechtikeit gotis unsirs herren, frisch und wolgesunt ist, wie wol das her dese somer etwas krankheit geleden hat, so schelet im doch von gnaden gottes iczund nicht me. ${ }^{84}$

Nevertheless, the letters usually provided more information. ${ }^{85}$ The news is diverse: sometimes only the fact of the illness is stated, and only one, probably the most striking feature of the disease, is mentioned; sometimes from the description of the recovery we can make the assumption that the person was sick for a while, or that he has been sick for a long time. ${ }^{86}$ There are at times, even if laconic, quite informative descriptions of the health status. ${ }^{87}$ For example, Vytautas, in a letter of 20 June 1430 to Russdorf informing him about the illness of the Vilnius Palatine Gedgaudas, Vytautas merely stated that he is czumale kranck uff seine beine, ${ }^{88}$ and the illness of Jaunius Valmantaitis is described laconically: der ist auch sich. ${ }^{89}$ He provided somewhat more complete information to his cousin Jogaila about the illnesses of his envoys. The foot illness of the Vilnius palatine, i.e. that a great pain in the feet had been tormenting him for a long time, and also that Jaunius had been sick for a

82 The definition of 'extended information' is very conditional, applied only in the context of the analysed sources, and only in this article.

$83 C E V$, no. 349 , p. 133 ; no. 356 , p. 139 ; no. 1273 , p. $762 ; L U B, B d .5$, no. 2522 , p. 705 ; no. 2523 , p. 707 ; Palacký I, no. 394 , p. 441; no. 397 , p. 445; no. 404, p. 457; Palacký II, no. 691, p. 157.

${ }^{84} C E V$, no. 349 , p. 133.

85 Ibid., no. 326 , p. 120 ; no. 356 , p. 139 ; no. 1213 , pp. $713-714$; no. 1270 , p. 759 ; no. 1418 , p. 907 ; $L U B$, Bd. 5 , no. 2522, pp. 704-705.

${ }^{86} C E V$, no. 356 , p. 139 ; no. 1270 , p. 759 ; no. 1273 , p. $761 ; L U B, B d .5$, no. 2522 , pp. $704-705$; no. 2577 , p. 791 .

87 CEV , no. 326 , p. 120 ; no. 1213 , pp. $713-714$; no. 1270 , p. 759 ; Codex diplomaticus Lithuaniae, no. 9, pp. 324-325.

${ }^{88} C E V$, no. 1418 , p. 907.

${ }^{89}$ Ibid. 
long time, were presented in detail. This information was provided to the Polish king:

Quod autem nobis scribit vestra serenitas in Ruthenico, quos de baronibus nostris ad predictam convencionem mittere vellemus, noverit vestra serenitas, quod decreveramus infra scriptos destinare, videlicet magnificos et strennuos Gedigoldum palatinum Wilnensem, Rumboldum terre nostre Lithvanie marschalcum, Petrassium capitaneum Novogrodensem et Gastoldum curie nostre marschalcum; sed quia maximo dolore pedis ipse Gedigoldus quassatur antiquo, et nec magis quam alias ob hoc transire non poterit; misissemus eciam Jawnum palatinum nostrum Trocensem, sed ipse laborat egritudine. ${ }^{90}$

The Livonian master, in a letter of 2 January 1421 to the grand master, said that the Archbishop of Riga was very sick and an old man: gnediger her meister, als wir euwir gnade vor geschreben haben, das unser herre ertzbischof zu Rige sere krankit und ein ald man ist. ${ }^{91} \mathrm{~A}$ few days later (on 6 January), in a letter written to the head of the Order, the Livonian master further developed the theme of the health of the Archbishop of Riga. He mentioned that he had already written to the head of the Order, and reported that he had also talked about health with the Archbishop of Riga. According to the Livonian master, the Archbishop of Riga had told him that he would not want to die in that country. ${ }^{92}$

Writing more broadly about their own health or that of other people, Vytautas and his correspondents would mention more signs of an illness or a recovery, and would describe more thoroughly their general well-being, for example, worsening or improving health. ${ }^{93}$ In letters, it was rarely written how long one was sick. ${ }^{94}$ When someone was sick for a long time, sometimes he would specify how long it had lasted, or would mention the changeable state of health, or that they had been sick for a while. ${ }^{95}$ So, sometimes from small clues, we can infer that he was sick not for a short time, or that the illness lasted a long time, and it was difficult and painful. For

${ }^{90} C E X V$, no. 180 , pp. 243-244.

${ }^{91} L U B$, Bd. 5, no. 2522, pp. 704, 705. In Čapaite, 'Sprawy zdrowia i chorób', p. 46 krak should be krankit.

${ }^{92}$ Item, gnediger her meister, wir haben euwirn gnaden ouch vor gescreben, wie das unser here von Rige selbin wedir uns gesprochen hot, das her ungerne in dessem lande wolde sterbin, LUB, Bd. 5, no. 2073, p. 707.

${ }^{93} C E V$, no. 356 , p. 139 ; no. 362 , p. 143 ; no. 1213 , pp. $713-714$; no. 1222 , p. 720 ; no. 1270 , p. 759 ; no. 1273 , pp. 761-762; Codex diplomaticus Lithuaniae, no. 9 , pp. $324-325$.

${ }^{94} C E V$, no. 1213 , pp. $713-714$; no. 1270 , p. 759 ; no. 1273 , pp. $761-762$.

${ }^{95}$ Ibid., no. 326 , p. 120 ; no. 362 , p. 143 ; no. 1213 , pp. $713-714$. 
example, Conrad von Jungingen, in a letter of 7 September 1405 to Vytautas, said:

Got weis, das wir deszen somer noch sinen gnaden vaste sverlich gelegen haben, alleine is doch besser worden ist, und itczunt von gotis hulfe wol wedir czu uns komen sint. ${ }^{96}$

In a letter hypothetically dated 29 March 1407 from Marienburg to Vytautas, the grand master briefly but powerfully described his state of health. According to the head of the Order, his health depended on the grace of Almighty God. So he sometimes had to lie down for a while until he felt better. In his letter, Konrad von Jungingen writes:

Ouch lieber besunder herre, schreiben wir euch gerne von unser gesundheit, sunder got der almechtige tut bi uns noch sinen gnaden, das wir uns also hin betragen iczunt gesunt, iczunt krank. Dorumme so haben wir willen uns of eine czeit ein legir czunemen, ab is mit uns bessir mochte werdin und bitten euch liber herre mit fleissiger begerunge, das ir uns geruchet ein klein czellen pferd czu senden, das werden wir zu unserm zatil halden, wen wir czu stunden so stark sint, so wellen wirs selbir riten. ${ }^{97}$

A changeable state of health is described, signs of poor health and the request for a small swift steed $^{98}$ that he could saddle himself, because at intervals he was so strong that he would like to ride, show that he had been severely ill. The letter is hypothetically dated 29 March 1407, and Konrad von Jungingen, after long sufferings, died in the castle of Marienburg on 30 March of the same year. ${ }^{99}$ According to the Chronicle of Johann von Posilge: Dornoch in den ostirheyligen tagen an der mitwochin undir der collacien vorstarb erwirdige brudir Conrad von Jungingen der homeister $[\ldots]{ }^{100}$

${ }^{96}$ Ibid., no. 326, p. 120.

97 Ibid., no. 326, p. 143.

98 Čapaite, 'Sprawy zdrowia i chorób', p. 47 states '[...] oraz wzmianka z prośbą o przysłanie mu koni [...]'. So it is not accurate that the grand master asked to send him a swift steed.

${ }^{99}$ M. Radoch, 'Wydatki wielkich mistrzów krzyżackich na placówki szpitalnie w Prusach w latach 1399-1409 (w świetle księgi podskarbiego malborskiego)', Komunikaty Mazursko-Warmińskie, 2007, 1 (255), p. 13; B. Jähnig, 'Konrad von Jungingen', Neue Deutsche Biographie, 12 (Berlin, 1980), p. 518. The author wishes to thank Dr Anna Kołodziejczyk of the University of Warmia and Mazury in Olsztyn for providing the opportunity to use the works of Poland's historians on this topic.

100 Johann von Posilge, Officials von Pomesanien, Chronik des Landes Preussen (von 1360 an, forgesetzt bis 1419), SRP, Bd. 3, p. 285. 
That Konrad von Jungingen was ill for a long time is confirmed not only by the correspondence, but also by entries in the expenditures book of the Order's treasurer for the medicines bought for him, the treatment, and the doctors treating him. ${ }^{101}$ For example, in 1405 a powder made for the grand master was paid for: item $1 \frac{1 / 2}{2}$. in die apoteke vor das pulfer, das unserm homeister gemacht wart. ${ }^{102}$ In 1406, the expenditures book of the Order's treasurer, noted that item 20 m. 7 scot. vor das gerethe, das her Birckhan us der apoteke nam zu des meisters notdorft, 14 tage vor vastnacht were dedicated to the needs of the grand master. ${ }^{103}$ Between approximately 9 February and 9 March of the same year, an entry indicates that these items were purchased for Konrad von Jungingen: Item $5 \mathrm{~m}$. dem apotheker vor das gerethe. das her Birckhan unserm homeister nam, am dinstage zur Oculi. item 3 fird vor 3 uncian buckblutes unserm homeister. ${ }^{104}$

The illness of Konrad von Jungingen is also recorded in chronicles. The long and severe illness of the grand master is mentioned in Posilge's Chronik des Landes Preußen. The chronicler states that Konrad von Jungingen was sick for three years, and he also names his illness: it was 'that stone', but stresses that the grand master was attacked fiercely by other diseases. The chronicle writes: Ouch so hatte der selbige homeister dry jar krang gewesin an deme steyne und andir krangheit, die in groslich obirgink. ${ }^{105}$ Historians identify the illness of Konrad von Jungingen in almost the same way. Bernhart Jähnig states that the grand masters's stones probably appeared before his early death. ${ }^{106}$ Marek Radoch says that in the last year of his rule, the grand master suffered from severe gallstones (it was bladder stones), from which he was sometimes

${ }^{101}$ Das Marienburger Tresslerbuch, pp. 85, 110, 122, 140, 284, 351, 366, 378, 380, 383, 393-394, 416, 418, 426; Broda, Lekarze w Państwie Zakonu Krzyżackiego, pp. $55-62,87,93,100,102,130-131,167$.

102 Ibid., p. 351.

103 Ibid., p. 393.

${ }^{104}$ Ibid., pp. 393, 394; Broda, Lekarze w Państwie Zakonu Krzyżackiego, p. 131.

105 SRP, Bd. 3, s. 285. The Latin name of the illness from which Konrad von Jungingen suffered is provided in Historia brevis magistrorum. It was Prefatus magister Conradus cepit egrotari calculo, Historia brevis magistrorum Ordinis Theutonici generalium ad Martinum Truchses continuata, M. Toeppen, SRP, 4, p. 265; M. Broda, 'Medical doctors from outside the Teutonic State in Prussia serving Teutonic Grand Masters in the 14th and the first half of the 15th centuries', Zapiski historyczne, vol. LXXVI, 2011, Book 3 (2013), s. 11.

106 Jähnig, 'Konrad von Jungingen', p. 518; Probst, Der Deutsche Orden, p. 161. 
even writhing in pain. ${ }^{107}$ Researchers who mention the illness and health of Konrad von Jungingen do not provide a single source. Michalina Broda, relying on sources, claims that the grand master was ill with gallstones; in her opinion, it was kidney stones as well as other diseases. ${ }^{108}$

From the 12 January 1422 letter from the Livonian master to the grand master, we can assume that the Livonian master had been ill for some time, maybe not for a short while. He had not recovered when the mentioned letter was written, because it says that with God's help, from day to day, he hopes for an improvement: wir nu mit der hulfe Gotis von tage zu tage besserunge hoffen. ${ }^{109}$ In a letter of a private nature of 13 January 1426 to Russdorf, Vytautas asked to send a good doctor of internal medicine for Grand Duchess Julijona as quickly as possible: leiparczt von innern sewchen. The entire letter by the grand duke is devoted to his spouse's illness and the search for a physician. Vytautas not only reported since when and for how long his wife was suffering, but also mentioned a few details of her state of health. According to the grand duke, Julijona had been ill for nearly a year, she complained day-to-day about her health, and could not eat anything. ${ }^{110}$ The Elbing komtur, in a letter of 2 May 1426 to the grand master, listed some of the symptoms of the seriously deteriorating health of the Polish King Jogaila, and emphasised that in a short time he had become greatly weakened. ${ }^{111}$

From the news about the illness and recovery provided by Vytautas and his addressees, it is difficult to decide what kind of illness it was. For example Sigismund of Luxemburg, notifying about an illness, also named it do vielen wir in krankheit mitnamen die sciatica des Ruckes. ${ }^{112}$ We may make the cautious assumption that the sciatica des Ruckes he was experiencing was sciatica. Specific symptoms of illnesses, or at least those considered as such, were very rarely indicated in the correspondence analysed. The highly visible, easily described, and specific signs of many diseases (e.g. internal fever,

107 Radoch, 'Wydatki wielkich mistrzów', p. 13.

108 Broda, 'Medical doctors', pp. 11, 12.

${ }^{109}$ LUB, Bd. 5, no. 2577, p. 791.

110 Wir thun euwer erwirdikeit czu wissen, wie das die irluchte frauwe Juliana, unser liebe hwszffrauwe wol von eime ganczen iare krank ist von gotes vorhenknisse und sider der czeit, als euwer erwirdikeit mit uns czu Garthen czusampne leczte was, ir kranheit hat czugenamen, also das sie von tage czu tage sich argert an ir gesundheit und nicht essen mag. CEV, no. 1213, pp. 713-714.

${ }^{111}$ Ibid., no. 1222, p. 720; Codex diplomaticus Lithuaniae, no. 9, pp. 324-325.

112 Palacký I, no. 397, p. 445. 
inability to eat, weak legs, foot pain) are generally mentioned, or it is just written that he is sick. ${ }^{113}$ The requests of Grand Duke Vytautas and King Jogaila of Poland to the grand master to send a physician from one area or another (e.g. an internal medicine doctor [leiparczt von innern sewchen] ${ }^{114}$ or an optician ${ }^{115}$ ) and entries in the expenditures book of the treasurer of the Teutonic Order about the visits of physicians and expenses for medicines, ${ }^{116}$ provide a little information about the illness. However, even in these cases, it remains unclear what illnesses the doctors were treating. In the material analysed, we may distinguish three groups of illnesses: of the eyes, the legs and internal.

There are data about problems with eyes in the correspondence ${ }^{117}$ and in the expenditures book of the Order's treasurer. ${ }^{118}$ For example, eye problems plagued Grand Master Ulrich von Jungingen ${ }^{119}$ and other officials of the Order, ${ }^{120}$ such as the Cracow palatine Jan Tarnowski. ${ }^{121}$ For instance, in 1409, an optician from Gdansk travelled to Ulrich von Jungingen. ${ }^{122}$ However, what illnesses these were, or what their symptoms were, I failed to detect in the sources analysed. ${ }^{123}$

In the letters of Vytautas and his addressees telling about illnesses, from time to time unhealthy feet are mentioned, 'weak legs', 'leg weakness', weakness in the legs, or foot pain (dolore pedis). ${ }^{124}$

${ }^{113} C E V$, no. 349 , p. 133 ; no. 356 , p. 139 ; no. 1270 , p. 759 ; no. 1273 , pp. 761 , 762; no. 1418 , p. 907.

114 Ibid., no. 1213, pp. 713-714.

115 Codex diplomaticus Lithuaniae, no. 4, p. 318; no. 7, pp. 321-322; no. 9, pp. 324-325; $C E V$, no. 1222 , p. 720.

116 Das Marienburger Tresslerbuch, pp. 119-120, 144, 165, 171, 223-224, $232,249,251,339,345,351-352,356,366,378,383,393-394,416,418,425$, $471,515,553$.

${ }_{117}$ CEV , no. 1222, p. 720; Codex diplomaticus Lithuaniae, no. 4, pp. 317-318; no. 7 , pp. 321-322; no. 9 , pp. 324-325.

118 Das Marienburger Tresslerbuch, pp. 119-120, 553; Broda, Lekarze w Państwie Zakonu Krzyżackiego, pp. 55-62, 65, 85, 91-96, 100-105, 107, 130, 165; Probst, Der Deutsche Orden, pp. 165-166.

119 Ibid., p. 553.

${ }^{120}$ Ibid., pp. 119-120.

${ }^{121}$ CEV, no. 1222, p. 720; Codex diplomaticus Lithuaniae, no. 7, pp. 321-322.

122 item 16 scot eyme furman, der den ogenarzte von Dancz zu unsern homeister furte, Das Marienburger Tresslerbuch, p. 553. Čapaite, 'Sprawy zdrowia i chorób', p. 49, errs in the date of the optician's visit: 1408 should be 1409 .

${ }^{123}$ Das Marienburger Tresslerbuch, pp. 119-120, 553.

124 GStAPK, OBA, no. 4562; CEXV, no. 180, pp. 243-244. 
Entries in the expenditures book of the Order's treasurer also testify to previous problems with feet. ${ }^{125}$ In the analysed sources, we can hypothetically distinguish two groups of foot problems: the first (according to the sources, more frequent) covers a wide range of accidents and injuries; the second is likely to be related to internal illnesses. The most mentions were about accidents (e.g. fractures) or injuries. For example, in the correspondence, foot pain is mentioned in the expenditures book of the Order's treasurer: the treatment of a leg or legs, or foot. ${ }^{126}$ For example, according to the entry of 8 or 9 January 1402, the wound doctor Wachsmut treated the foot of the young brother Seckkendorff. In the record, it is briefly noted: Item $1 \mathrm{~m}$. Wachsmut dem wundarzte, das her dem jungen bruder Seckkendorff den füs heilte, am montage nach dem obirsten tage. ${ }^{127}$

Problems with legs associated with internal diseases are called weaknesses of legs, weakness in the legs in the letters of Vytautas and his correspondents or it is stated that the legs are unhealthy. These ailments of the feet most likely could have been of a dual nature. One, they were really some kind of leg disease or accident; two, it could have been the symptom or effect of an internal disease. As has already been mentioned, in 1430, Vytautas described the illness of the Vilnius palatine Gedgaudas: he is kranck uff seine beine. ${ }^{128}$ However, in the letter to Jogaila, he stated that Gedgaudas was suffering from an old great pain in the foot sed quia maximo dolore pedis ipse Gedigoldus quassatur antiquo. ${ }^{129}$ So the saying 'unhealthy legs' could have described a foot trauma, because the result is the same, an unhealthy foot; however, it could also be a foot illness, or a symptom or a consequence of an internal illness. In some cases, when in the expenditures book of the Order's treasurer a leg or foot treatment is recorded and the wound doctor (wundearzt) treated the injuries, but an accident is not specified, we can make the cautious assumption that it might have been an illness of the legs, or the consequence of an internal illness. Nevertheless, it could be an illness of the legs or the consequence of internal medicine when the treating doctor is called (artz). For example, in the ledger of the

125 Das Marienburger Tresslerbuch, pp. 80, 144, 223, 352.

${ }^{126}$ CEXV, no. 180, pp. 243-244; Das Marienburger Tresslerbuch, pp. 144, 232,352 .

${ }^{127}$ Ibid., p. 144.

${ }^{128}$ CEV, no. 1418, p. 907; Petrauskas, Lietuvos diduomené, pp. 247-248.

${ }^{129}$ CEXV, no. 180 , pp. 243-244. 
treasurer of the Teutonic Order, the entry for the date 14-15 July 1400 indicates that the doctor treated the legs of one Haszen. ${ }^{130}$

According to the available data, it is not possible to determine what internal illnesses the persons had. In this article, these symptoms mentioned in the letters are associated with internal illnesses: internal fever, inability to eat, weakness in the legs, just the statement that he is sick, a long-running changeable state of health, or poor general feeling. ${ }^{131}$ For example, Konrad von Jungingen described his long-lasting changeable state of health (now we are healthy, now we are sick) wir uns also hin betragen iczunt gesunt, iczunt krank. ${ }^{132}$ However, we should note that the features named are characteristic of many illnesses, so it could be the consequences of a number of illnesses or injuries.

As has already been mentioned, in a letter of 18 March 1426 to the Polish king, Sigismund of Luxemburg expressed his sorrow at the deplorable event (casu lugubri) ${ }^{133}$ afflicting him (Jogaila). With the deplorable event mentioned by the King of the Romans, we can also likely relate that in the letter of 22 March 1426 to the grand master, Jogaila, after thanking him for the falcons sent, mentioned that he was suffering from foot pain. Stanisłav Ciołek, the Deputy Chancellor of the Kingdom of Poland, in an addition to the letter of Sigismund of Luxembourg to Jogaila, indicated that the King of the Romans expressed his sympathy for Jogaila for the major leg injury. ${ }^{134}$ The note reads: Littera compassionis Romanorum regis super offensa pedis domini regis Polonie. ${ }^{135}$ Having published the letter, Caro pointed out that there is more information in the letter than Ciołek provided in the addition to the letter. Commenting on the injury of the King of Poland, Caro indicated that Długosz allegedly said that Jogaila broke his leg during a bear hunt. The historian relied on two other sources, the already mentioned 2 May 1426 letter from the Elbing komtur to the grand master, and Johann

130 ... dem arzte der her Haszen arztigete an syme beyne, am dornstage noch Margarethe, Das Marienburger Tresslerbuch, p. 80.

$131 C E V$, no. 356 , p. 139 ; no. 362 , p. 143 ; no. 1213 , pp. $713-714$; no. 1270 , p. 759 ; no. 1273 , pp. 761-762; no. 1418 , p. 907.

$132 \mathrm{CEV}$, no. 362, p. 143.

133 Liber cancellariae, no. 93, p. 170; Palacký I, no. 394, p. 441; CEV, no. 1217 , p. 717.

134 GStAPK, OBA, no. 4562.

135 Liber cancellariae, no. 93, p. 170. Čapaitè, 'Vèlyvųjų viduramžių epistolika', p. 70-71 claims wrongly that Sigismund expressed sympathy for Jogaila's aching leg. 
Voigt's work Geschichte Preussen for the specified signs of the ailments of Jogaila. ${ }^{136}$ Having published the letter from the King of the Romans, Palacký indicated the publication of Caro, in the addition to the letter, which stated that Sigismund of Luxemburg expressed his sympathy for the King of Poland for the broken leg, and listed the other topics in the letter. The researcher did not mention any circumstances relating to the leg injury of Jogaila. ${ }^{137}$ Antoni Prochaska did not publish the letter of Sigismund of Luxemburg, but only provided a thorough annotation (he listed the main topics of the letter), and pointed out where it was published. Just like Palacký, the researcher said that the King of the Romans expressed his sympathy for Jogaila for the broken leg, but did not indicate any circumstances relating to this event, the accident, or where it is talked about. ${ }^{138}$

We need to pay attention to a few things here. Sigismund of Luxemburg expressed his sympathy for Jogaila for the 'deplorable incident' (casu lugubri), but did not mention what it was. Ciołek, in the annotation to the letter, already states that the King of the Romans regretted the super offensa pedis domini regis Polonie. ${ }^{139}$ However, as has already been mentioned, the letter of Sigismund of Luxemburg is multi-thematic, and the deputy chancellor indicated only that one. We can assume that this topic seemed to him to be the most important, or indicated only it, because the letter of Sigismund of Luxemburg, after the referral to Jogaila, begins with the statement of sympathy for him. We can assume that Ciołek knew what had happened, so he 'specified' the deplorable event that the King of the Romans lamented. Ciołek's specifications also confirm that in the 22 March 1426 letter of Jogaila to the grand master, there is a mention of the foot pain tormenting him. ${ }^{140}$

As has already been mentioned, the Elbing komtur in a letter of 2 May 1426 written from Torun to the grand master, along with various current political affairs, reported the deterioration in the health of the Polish king. The official indicated some of the signs of the deteriorating health of Jogaila. According to the Elbing komtur, at that time one could see the great illness of the legs and the weak-

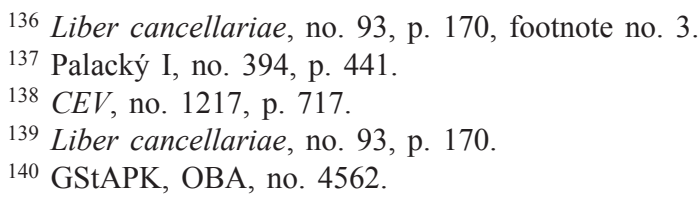


ness of the king, so that they even had to carry him off the ship. He emphasised that Jogaila became very weak in a short time. In the letter, the komtur wrote:

An dem herren konige uff die czeit sogen grosse kranckheit und swacheit der beine, das man in och us dem schiffe tragen muste, von andern den sinen sine swacheit ouch wol vornomen die sine gnoden binnen korczen cziten sere hat geswechet. ${ }^{141}$

Having published the letter of the Elbing komtur, Prochaska provided with the account of Jogaila's health a reference to the work of Długosz, and briefly summarised that allegedly the chronicler related that the king had broken his leg during a bear hunt. ${ }^{142}$ So Jogaila had suffered a deplorable event, the pain in Jogaila's foot was reflected in the chronicles, but acquired new details. Długosz, telling about a misfortune that occurred in the hunt, ${ }^{143}$ not only indicated the time and place of the event, but also the fact that the king spent Shrovetide and forty days of fast (it is Lent time) healing his damaged bone. ${ }^{144}$ The chronicler says that after Easter (it was on 31 March 1426), during the octave, Jogaila with the already healed leg sailed in a boat on the Wistuła to Kujawy. ${ }^{145}$ So Długosz does not mention any weakness, on the contrary, says that the King of Poland at that time was already healthy. Johann Voigt describes the health status of Jogaila contrarily.

Johann Voigt, telling about the 1426 meeting in Torun between Jogaila and officials of the Order, described the infirmity of the King of Poland almost in the words of the Elbing komtur. The chronicler emphasised that at the time Jogaila suffered greatly, and due to a

${ }^{141}$ CEV, no. 1222, s. 720; Codex diplomaticus Lithuaniae, no. 9, pp. 324-325; Čapaite, 'Sprawy zdrowia i chorób', p. 48, omits the word sine.

${ }^{142}$ CEV , no. 1222 , p. 721.

143 [...] dum Wladislaus Polonie Rex apud Vilnam cum consorte sua Sophia Regina exegisset, et ante Carnisprivium ex Lithuania redire in Poloniae Regnum, peste conquiescente, inciperet, in loco venationum, qui appellatur Byalowyesze, venationi ursi insistens, casualiter pedem fregit, et exinde in terram Chelmensen discedens, dies Carnisprivii et tempus Quadragesimae in Lubomlya et Krasznistaw, crus offensum medemdo, absumpsit. Acta est autem pro Quadragesimae medio in oppido Wartha conventio generalis. Ad quam licet Wladislaus Poloniae Rex proter pedis languorem non venisset, consiliarii tamen principales illuc convenientes tractabant [...]. Ioannis Długossii seu Longini Canonici Cracoviensis, Historiae Polonicae, p. 337.

144 J. Dlugossii, Annales seu cronicae incliti regni Poloniae, J. Dugosza Roczniki czyli kroniki sławnego królewstwa Polskiego, księga XI: 1415-1450 (Warsaw, 1985), p. 226.

145 Ibid., p. 227. 
serious illness he was so weakened that he had to be carried on and off the ship. He also added that the grand master, at the request of the king, sent his best doctor (see below). According to the historian:

er war überdieß sehr leidend, denn eine schwere Krankheit hatte ihn so geschwächt, $d a ß$ er bei seiner Reise zu Schiff aus=und eingetragen werden mußte, weshalb ihm auch auf seine Bitte der Hochmeister seinen besten Arzt entgegensandte. ${ }^{146}$

Voigt, in the provided reference to the description of the king's health, explained that, according to Długosz, Jogaila broke his leg while hunting bears. So the king's illness, although indirectly, was linked to a hunting accident.

Based on the Elbing komtur's description of the health status of Jogaila, it is not possible to determine what the cause of the illness was, or what illness he had. However, the trend in historiography to link the illness of the King of Poland, not focusing on it too much, with the foot broken while hunting goes on and on. For example, Jan Tęgowski says that in a letter from the Elbing komtur it is purportedly written that at that time the King of Poland had a broken leg. ${ }^{147}$ Here we need to emphasise that it is not written in the letter of the Order's official that Jogaila had a broken leg. In the information submitted by the Elbing komtur ${ }^{148}$ we can identify relatively two stages in the illness: a) a serious illness and weakness in the legs; b) within a short time there occured a general weakness of the king. Now we can only hypothetically consider whether the 'deplorable incident' (casu lugubri) mentioned in the letters of Jogaila and his correspondents, large foot injury (super offensa pedis), foot pain, grosse kranckheit und swacheit der beine fixed by the Elbing komtur, and the great weakening of Jogaila were related. As has been mentioned, such links have been made in historiography. Here attention should be paid to a few points. Sigismund of Luxemburg lamented the deplorable event in a letter to Jogaila on 18 March 1426. Jogaila mentioned the great foot pain in a letter to the grand master on 22 March of the same year. Hypothetically, we can consider that Jogaila suffered the accident at the beginning or

146 J. Voigt, Geschichte Preussens von den ältesten Zeiten bis zum Untergange der Herrschaft des Deutschen Ordens, Bd. 7: Die Zeit vom Hochmeister Ulrich von Jungingen 1407 bis zum Tode des Homeisters Paul von Rußdorf 1441 (Königsberg, 1836), p. 484.

147 J. Tęgowski, 'Kilka uzupełnień do itinerarium króla Władysława Jagiełły', Studia Źródtoznawcze, 41, 2003, p. 84.

148 Codex diplomaticus Lithuaniae, no. 9, pp. 324-325; CEV, no. 1222, p. 720. 
in the first half of March. The letter of the Elbing komtur is dated 2 May 1426, and it states that at the time the great illness and weakness of the king's legs (uff die czeit sogen grosse kranckheit und swacheit der beine) could be seen. So probably we are talking about a malaise lasting more than one and a half months. So the disease and weakness of the legs of Jogaila may be incurred, but the consequence of the accident is unclear. However, it could just as well have been some kind of illness of the legs, or some kind of symptom or consequence of an internal disease that caused the rapid weakening of the ruler.

Very rarely are there writings about signs of recovery, such as feeling better or stronger, being able to walk or sit, being perky, able to ride, and finally being completely healthy. ${ }^{149}$ Nevertheless, the signs of recovery mentioned can also sometimes mean that there had been an internal disease. ${ }^{150}$ For instance, in a letter of 17 March 1427 to Russdorf, Vytautas, among the most varied relevant political events and news, also reported an improvement in his health. The grand duke indicated how long he had been sick, and enumerated the signs of recovery. According to the grand duke, on Friday it was three weeks since he became sick, but now with the help of God he feels better. So he is walking, standing and sitting, but still suffering a little bit of heat from an inner fever. ${ }^{151} \mathrm{He}$ mentioned that Julijona was also sick. ${ }^{152}$ Vytautas was well again in April 1427. He wrote about this in a multi-topic letter of 6 April 1427 to the grand master. ${ }^{153}$ Perhaps the most important sign of his full recovery was that he was already riding to hounds. According to the grand duke: und [wisset von] gotes gnaden wir sein wol gesund und [uff] die jahit iczund reiten [...]. ${ }^{154} \mathrm{He}$ reported that with God's help, the health of the grand duchess also improved completely: desgleich

${ }^{149} C E V$, no. 349 , p. 133 ; no. 362 , p. 143 ; no. 1270 , p. 759 ; no. 1273 , p. 762.

${ }^{150}$ Ibid., no. 362 , p. 143 ; no. 1222 , p. 720 ; no. 1270 , p. 759.

${ }^{151}$ Auch sint is am freitage drei wochen [gewest] daz wir krank woren, sunder nu mit gottes hulfe ist uns bas wurden, also daz wir nu geen, steen und siczczen, alleine daz wir noch ettwas bei innen hiczcze leiden..., CEV, no. 1270, p. 759.

152 Auch so i[st] di irluchte unser libe hausfrawe noch krank, sundir wir auch ir besserunge czu gotte getrawen, ibid., no. 1270, p. 759.

153 Ibid., no. 1273, pp. 761, 762.

${ }^{154} C E V$, no. 1273 , pp. 761,762 ; In the article Čapaite, 'Sprawy zdrowia i chorób', p. 48, there is a typographical error in this quotation: wir seinwol gesund should be wir sein wol gesund. 
ouch mit gotis hulfe sich iczunt wol bessert. ${ }^{155}$ So we can say that the grand duke was sick for a long time. According to the correspondence, hypothetically, we can consider that he fell ill in late February or early March. In a letter of 17 March 1427 to Russdorf, the described health of Vytautas shows that at that time he was not yet completely better. He was well only at the beginning of April. Hence, he was sick for more than a month. Considering the illness was not short, from the signs of recovery listed we can assume that he was seriously ill, and that it was some kind of internal disease. But which one, I failed to find out.

Doctors of three specialisations are mentioned in the analysed correspondence and the expenditures book of the Order's treasurer: eye doctor or optician (ougenarzt, ogenarzt, medicus oculista, medicus eculista), ${ }^{156}$ wound doctor (wundarzt, wundearzt, wondearzt), ${ }^{157}$ i.e. surgeon, ${ }^{158}$ and only once is there talk about an internal diseases doctor (leiparczt von innern sewchen). In the expenditures book, often simply 'doctor' (arzt) was written. ${ }^{159}$ It is also indicated where the doctor was from (e.g. 'arzt von Thorun'), ${ }^{160}$ or arzt, the doctor's name and where he was from (hern Niclus Birkhayn dem arzte von Danczk). ${ }^{161}$ Often magister (magistro Johanni, magistro Bartholomeo) ${ }^{162}$ or 'magister Bartholomeus arzt'163 is identified or often meister (e.g. meister Johan, meister Birhayn, meister Bartholomeus), ${ }^{164}$ it was also written e.g. magister Johannes der arzt, meister Johann der arzt or magister Bartholomeus arzt. ${ }^{165}$ Often the status of the doctor was indicated, for example, the doctor of the grand master (e.g. magistro Johanni des meisters arzt, magistro Johanni unsers homeisters arzte, meister Birhayn des meisters

155 CEV, no. 1273 , p. 762.

156 Ibid., no. 1222, p. 720; Codex diplomaticus Lithuaniae, no. 7, pp. 321-322; Das Marienburger Tresslerbuch, pp. 112, 119-120, 553.

157 Ibid., pp. 144, 165, 171, 223-224, 226, 232, 249, 251, 339, 345, 352, 356, 379, 416, 418, 425, 471, 515.

158 Broda, Lekarze w Państwie Zakonu Krzyżackiego, pp. 9-10, 90-105, 107. Radoch, 'Wydatki wielkich mistrzów', s. 12.

159 Das Marienburger Tresslerbuch, pp. 75, 80, 141, 254, 342, 428, 461, 502.

160 Ibid., pp. 254, 428.

161 Ibid., p. 365.

162 Ibid., pp. 38, 178, 478, 547, 563.

163 Ibid., p. 528.

164 Ibid., pp. 85, 122, 245, 366, 380, 383, 416, 425, 476, 498, 514, 542, 547.

165 Ibid., pp. 64, 81-82, 96, 110, 119, 122-123, 277, 283-284, 316, 366, 528, 538. 
arzte and others). ${ }^{166}$ Sometimes her (her Birhay) ${ }^{167}$ was written. Max Töppen identified three classes of the grand master's servants. The doctors were in the second class (eine zweite Klasse), which, according to the grouping of the researcher, consisted of scholars, artists and lawyers. ${ }^{168}$

In the recorded visits of eye doctors, it is not mentioned what illnesses were treated. ${ }^{169}$ In the entries of the expenditures book of the Order's treasurer about the services of the wound doctor (wundarzt), it is often indicated what condition was treated (e.g. various injuries, ${ }^{170}$ fractures). ${ }^{171}$ For example, the wound doctor treated the fractured leg of one patient, the fractured hand of another. In the expenditures book, on 1 August 1401 it is noted that

item $2 \mathrm{~m}$. Wachsmut geben vor eynen hengisknecht, der eyn byn hatte gebrochen, und vor eynen karwansknechte, der eynen arm hatte gebrochen, am donrstage vor Dominici confessoris. ${ }^{172}$

Between 11 and 26 May 1403, it is recorded that during the winter march the surgeon treated the shot finger of Niclus von Schillingsdorff: item $3 \mathrm{~m}$. dem selben, das her Niclus von Schillingsdorff den finger heilte, der ym zwyr in der winterreise wart durchschossen [...]. ${ }^{173}$

However, often only the patient is indicated, but it is not stated what he was treated for. ${ }^{174}$ For example, according to the 18 July 1402 entry, a wound specialist called Wachsmut treated the grand komtur: Item $4 \mathrm{~m}$. Wachsmuten deme wundarzte gegeben, als her den groskompthur gearztyget hatte. ${ }^{175}$ In such cases, we could make the cautious assumption that the surgeon's work could be related to

166 Ibid., pp. 140-141, 182, 240, 252, 298, 342, 378, 381, 419, 476.

167 Ibid., pp. 393-394, 418.

${ }^{168}$ Eine zweite Klasse von Dienern waren die Gelehrten, Künstler und Techniker ... Hieher gehörten ferner die Aerzte in Konrads von Jungingen Zeit, besonders der Magister Johannes, neben dem in Marienburg auch noch ein Augenarzt, Meister Conrad, ein Wundarzt Wachsmuth, noch ein anderer Wundartz Gerke ... erwähnt werden, Historia de Ordine Theutonicorum cruciferorum von Laurentius Blumenau, hrsg. von Max Toepen, SRP, Bd. 4, p. 111.

169 Das Marienburger Tresslerbuch, pp. 119-120, 553.

170 Ibid., p. 249.

${ }^{171}$ Ibid., pp. 80, 120, 144, 223, 232, 249, 252, 352. Broda, Lekarze w Państwie Zakonu Krzyżackiego, pp. 91-100.

172 Das Marienburger Tresslerbuch, p. 120.

173 Ibid., p. 249.

174 Ibid., pp. 165, 171, 224, 249, 251, 339, 345, 356, 418, 425, 471, 515.

175 Ibid., p. 171. 
some kind of trauma (injury) or some kind of internal disease, the treatment of which required surgical intervention.

When talking about the work of doctors (arzt), only their patients are indicated, ${ }^{176}$ sometimes the condition of the patients is mentioned (e.g. bey arzte lag, krank lag). ${ }^{177}$ But not even once is it mentioned what diseases they were treating. Nevertheless, we may formulate the cautious hypothesis that in the expenditures book of the Order's treasurer, people called doctor (arzt) were probably internal medicine doctors. This assumption is supported by the personalities and education of the doctors, their status, practice and correspondence. ${ }^{178}$ The most often mentioned are Johann, Niclus Birghayn and Bartholomew of Boreszewo. In the expenditures book, Johann Rogge is called only by his name and his education, or education and speciality, or education, speciality and status (e.g. meister Johannes, meister Johannes unsers homeisters arzt, magistro Johani unsers homeisters arzte). ${ }^{179}$ Niclus Birghayn (Birkhayn, Birghan) is described by his name and last name, often only the last name, and it would indicate the speciality and where he is from (hern Niclus Birkhayn dem arzte von Danczk, ${ }^{180}$ her Birckhan, ${ }^{181}$ her Birghayn von Danczk, ${ }^{182}$ meister Birghan den arz; sometimes it would indicate the status, meister Birghayn des meisters arzte. ${ }^{183}$ Bartholomew of Boreszewo is called by his name, his education degree is indicated, and sometimes his speciality or duties and status (e.g. meister Bartholomeus, Magister Bartholomeus arzt). ${ }^{184}$

176 Ibid., pp. 279, 425, 428, 461, 502.

177 Ibid., pp. 279, 436.

$178 C E V$, no. 359, p. 141; Broda, 'Medical doctors', pp. 12, 15, 16; eadem, 'Bartłomej z Boreszewa - dziekan warmiński, lekarz, dyplomata przełomu XIVXV a.', Ludzie, krórzy zmienili bieg historii, ed. A. Piwek, B. Pinkiewicz-Gara, K. Rajczakowski (Wrocław, 2010), pp. 33-38; A. Świeżawski, 'Bartłomiej z Boreszewa lekarz wielkich mistrzów krzyżackich', Archiwum Historii Medycyny, 24 (1964), p. 370.

179 Das Marienburger Tresslerbuch, pp. 64, 71, 81-82, 96, 110, 122-123, 140-141, 177-178, 182, 199, 240, 252, 277, 283-284, 288, 298, 310, 316, 342, 366, 378, 538; Historia de Ordine Theutonicorum, SRP, 4, p. 111; Probst, Der Deutsche Orden, pp. 162-163; Broda, 'Medical doctors', pp. 12-20.

180 Das Marienburger Tresslerbuch, p. 365.

${ }^{181}$ Ibid., pp. 393-394, 418.

182 Ibid., p. 387.

${ }^{183}$ Ibid., pp. 338, 366, 380-381, 383, 419; Broda, 'Medical doctors', p. 12.

${ }^{184}$ Das Marienburger Tresslerbuch, pp. 38, 278, 383, 416, 425, 430, 476, 478, 498, 514, 528, 542, 547, 561, 563; Broda, 'Medical doctors', p. 12; eadem, 'Bartłomej z Boreszewa', pp. 33-34; Świeżawski, 'Bartłomiej z Boreszewa', pp. 371-380. 
Attention is given to doctors in the letters of Vytautas and his addressees. They looked for good and trustworthy, or just more famous doctors, about some of whom they had heard. If necessary, they asked for them to be sent. The data in the letters are supplemented by entries in the expenditures book of the Order's treasurer and in the court accounts of King Jogaila about the visits of doctors. In the expenditures book of the Order's treasurer and in letters, doctors from Toruń, ${ }^{185}$ Elbing ${ }^{186}$ and Gdańsk ${ }^{187}$ are mentioned. Doctors would visit the rulers and people in their immediate circle. However, sometimes patients travelled for medical treatment. In 1393, on the instruction of the King of Poland, appotecarius Andreas was sent to Ona, the wife of Vytautas. ${ }^{188}$ Rimvydas Petrauskas calls him a doctor. ${ }^{189}$ Nevertheless, it is not clear whether Andreas was a doctor. It should be noted that in both the correspondence and in the accounts of the estate of the King of Poland, when talking about doctors, the term medicus was used. ${ }^{190}$ In the expenditures book of the Order's treasurer, it was recorded that in 1401, on the instructions of the grand master (the entry is dated between 23 and 25 March) an eye doctor (ogenarzt) was sent to Vytautas. ${ }^{191}$ This visit is not reflected in the surviving correspondence. We can assume that its details were coordinated through messengers or trustworthy persons. It also remains unclear whether the doctor or optician was needed for Vytautas himself or for someone else. In each case, the head of the Order sent an optician at the request of Vytautas. The requests in 1426 from the King of Poland to the Elbing komtur to send an

${ }^{185}$ CEV, no. 1213, pp. 713, 714; Codex diplomaticus Lithuaniae, no. 9, pp. 324, 325; Das Marienburger Tresslerbuch, pp. 428, 502.

${ }^{186}$ Ibid., pp. 75, 591.

187 Ibid., pp. 254, 365, 436, 553.

188 item Andree appotecario pro confectubus et electuariis missis dne ducisse Witoldi ad mandatum dni Regis VII marc., Rachunki dworu króla Władystawa Jagielty, p. 156.

189 R. Petrauskas, 'Kszałtowanie się instytucji dworu wielkoksiężęcego w Wielkim Księstwie Litewskim (koniec XIV - połowa XV wieku)', Politeja, 2011, no. 2(16), p. 183.

190 Rachunki dworu króla Władystawa Jagietly, p. 215; Codex diplomaticus Lithuaniae, no. 4, p. 318; no. 7, pp. 321-322.

${ }^{191}$ Das Marienburger Tresslerbuch, p. 70; A very similar entry is dated also to 1401: Item III. mark deme ogenarczte den der meister czu herczoge Wytowdt gesant hatte von des meisters geheise am tage annunciacionis Marie her Truppurg his uns das geld geben, CEV, Appendix, p. 962. However, there is no entry in 1400. It was unable to determine whether the eye doctor was sent to Vytautas one or two times. Broda, Lekarze w Państwie Zakonu Krzyżackiego, pp. 100-101, 169. 
eye doctor for the Cracow palatine Jan Tarnowski presuppose the consideration of whether Vytautas or someone else needed the help of an optician. In 1426, Jogaila asked the Elbing komtur travelling to the congress taking place in Nieszawa and Torun also to take an eye doctor (medicus oculista, medicus eculista). The king explained the request in letters of 24 and 27 April 1426 to officials of the Order. ${ }^{192}$ A doctor was needed for the Cracow palatine Jan Tarnowski. ${ }^{193}$ The Elbing komtur in a letter of 2 May 1426, informed Russdorf about this, stating that the King of Poland was asking to send as soon as possible an eye doctor, and forwarded the letter received from Jogaila. ${ }^{194}$ Not knowing the whole story of the search for an optician, we can form the misleading impression from only the statement of the Elbing komtur that the King of Poland, and not the Cracow palatine, needed the assistance of an optician. It would be useful to draw attention to one more detail. Jogaila did not mention the doctor's name. However, the Elbing komtur says that the king was asking to send meister Heinrich den ougenarczt. ${ }^{195}$ From the analysed sources, it remains unclear whether the komtur himself decided that they had to send Heinrich, bearing in mind his high qualification. It may be that there were conversations or other sources of information from which it was decided that the king wanted Heinrich to treat the Cracow voivod. As has been mentioned, sending the eye doctor probably found an echo in Voigt's work,

192 Codex diplomaticus Lithuaniae, no. 4, p. 318; no. 7, pp. 321-322.

${ }^{193}$ Nam vobiscum habemus aliqua ardua et opurtana pertractare Ceterum prout alias Magistro generali Compatri nostro carissimo et vobis scriptis nostris pro medico intimauimus petentes ut ad curandum egritudinem magnifici Johannis de Tharnow palatini Cracouien. baronis nostri sincere dilecti per vos fuisset ordinatus. Et quia iam idem Maguificus Johannes Palatinus ad nos venit et vadit usque in Neschowam nobiscum. Ideo vos petimus vt eundem medicum vobiscum aducatis $v t$ idem medicus in mense majo circa egritudinem suam aliquid salubri operetur, Codex diplomaticus Lithuaniae, no. 4, p. 318.

194 so senden wir euch dissen ingeslossenen des herren koniges brieff uns gekomen uff dem hinczoge ken Thorun. Mit fleissiger begerunge bittet der herre konig umb meister Heinrich den ougenarczt, das euwer erwirdikeit seinen gnoden wolde schicken io ee io besser und unvorczogen, dem wir ouch geschreben haben czu komen daran euwer erwirdikeit im gancz groslich thete czu danken, CEV, no. 1222, p. 720; Codex diplomaticus Lithuaniae, no. 9, pp. 324-325. Čapaite, 'Sprawy zdrowia i chorób', p. 53, footnote no. 138, quotes from Codex diplomaticus Lithuaniae, no. 9, pp. 324-325. In the publications of this letter provided by A. Prochaska (CEV, no. 1222 , p. 720 ; no. 9, p. 324-325), the writing of some of the words differs.

${ }^{195}$ CEV, no. 1222, p. 720; Codex diplomaticus Lithuaniae, no. 9, pp. 324-325. 
but only some details were changed. The chronicler, describing the weakness of Jogaila, said that at the request of the King of Poland, the grand master sent him his best doctor. ${ }^{196}$

In April 1400, Mattis, a servant of Vytautas, was looking for a doctor in the Order. In the expenditures book of the Order's treasurer, there are two entries on this topic, and in them Mattis is named differently, so his status remains unclear. In the entry of 13 April 1400, it is indicated that 1.5 marks were given to the servant of Vytautas Mattis, ${ }^{197}$ and according to the 15 April entry the messenger of Vytautas Mettis (probably the same Mattis) was given 15 scot and six pfenge: item 15 scot und 6 pfenge Mattis herzogen Wytowdts bothe us der herbergen zu losen zum andren mole, alzo her den artz suchte. ${ }^{198}$ What speciality Mattis was seeking a doctor of and who the patient was remain unanswered.

In 1426, Vytautas, asking Russdorf to send a good internal medicine doctor (leiparczt von innern sewchen) as soon as possible for Grand Duchess Julijona, said that he had heard that they were praising one doctor in Torun very much. According to the grand duke, the grand master may know this better, so send him or another, the best one available, regardless of whether he is in his castle (at home) or in the state. In the letter, Vytautas writes:

Hirumme wir bitten euwir erwirdikeit fleissiclich, ist das ir in euwirm hause adir euwirm lande habit irneinen gutten leiparczt von innern sewchen, und als wir horen das man einen czu Thorun lobit, ir mogit bas wissen, das ir uns den io ee io besser wellit schicken. ${ }^{199}$

Heinrik, the famous Torun doctor, was sent to Julijona. ${ }^{200}$ It is hard to say how quickly the doctor arrived, and how long he treated her. Thanks to his treatment, the health of the grand duchess improved. We can only confirm that the request by Vytautas to send a doctor is dated 13 January 1426 in Oboltsy, an estate between Vitebsk and Smolensk (Gebin czu Obolecz in unserm hoffe czwuschen Witewsk und Smolensk). On 25 January

196 Voigt, Geschichte Preussens, Bd. 7, p. 484.

197 item 11/2 m. Mattis herzogen Wytowdts dyner us der herbergen zu losen, der den artz suchte, am dinstage noch palmen, Das Marienburger Tresslerbuch, p. 72.

198 Ibid., p. 73.

199 CEV , no. 1213, p. 714; Čapaite, 'Sprawy zdrowia i chorób', p. 54: is das ir in euwirn should be ist das ir in euwirm; euwir lande should be euwirm lande; uns den o ee io besser should be uns den io ee io besser.

${ }^{200}$ CEV, no. 1216, p. 716; A. Prochaska, Ostatnie lata Witolda. Studyum z dziejów intrygi dyplomatycznej (Warsaw, 1882), pp. 60, 62. 
1426 , in a letter written from Vitebsk to the head of the Order, Vytautas mentions neither his wife's illness nor the doctor. ${ }^{201}$ Vytautas arrived in Dubyčiai on 25 February. On the next day (i.e. 26 February 1426), at the end of a letter written from Dubičiai to Russdorf, after current political affairs (e.g. the issue of the Liubice mill), the grand duke informed him that on returning he had found the doctor and his wife feeling better. We can assume that Heinrich treated Julijona for about a month. The grand duke thanked the head of the Order for sending the doctor, and asked that Heinrich be allowed to stay with them for some time. ${ }^{202}$ Russdorf let the doctor stay until the grand duchess was totally recovered. ${ }^{203}$

Doctors in several specialities (internal medicine, wounds) ${ }^{204}$ treated Konrad von Jungingen, who was ill for a long time. ${ }^{205}$ Not only the doctor with the status of the physician of the grand master cared for him, but also doctors from elsewhere. ${ }^{206}$ In the 30 May 1404 entry in the expenditures book of the Order's treasurer, it is stated that a doctor from Gdańsk came to Konrad von Jungingen and took care of him: Item $10 \mathrm{~m}$. dem arzte gegeben, der von Danczk zu unserm homeister qwam und bey im was, do her krank was [...]. ${ }^{207}$ Most likely, he was a doctor of internal medicine. According to the entries in the expenditures book of the Order's treasurer, Konrad von Jungingen's doctor (defining his status as a doctor, he is named des meisters arzt, unsers hochmeisters arzt) at

${ }^{201}$ CEV , no 1214 , pp. 714-715.

${ }^{202}$ Item als wir her gestern komen sein, habin wir funden euwirn arczt maister Henrich, den ir uff unser bete czu uns gesant habit, und wie wol, des gedancket sei gote, unser hwsfrauwe sich iczund gehat bas an erer gesuntheit, wir wellen doch egenanten meister Heinrich einweil noch bei uns enthalten, vor welchs sendunge dancken wir ouch euwir erwirdikeit fruntlich sere, CEV, no. 1216, p. 716. Čapaite, 'Sprawy zdrowia i chorób', p. 54, footnote no. 143: euwir arczt maister henrich should be euwirn arczt maister Henrich; basa $n$ erer gesuntheit should be bas an erer gesuntheit.

203 Prochaska, Ostatnie lata Witolda, pp. 60, 62.

${ }^{204}$ SRP, Bd. 3: Die Geschichtsquellen der Preussischen Vorzeit bis zum Untergange der Ordensherrschaft, p. 285.

${ }^{205}$ Das Marienburger Tresslerbuch, pp. 182, 298, 342, 378, 381, 425, 476, 542; CEV, no. 359, p. 141; Geschichten von Wegen eines Bundes von Landen und Steten. Wider den Orden unser lieben Frawen und die Bruder desselben Ordens im Lande zu Prussen geschehen, SRP, Bd. 4, p. 111; Broda, 'Medical doctors', pp. 12, 19-20; Świeżawski, 'Bartłomiej z Boreszewa', p. 371.

206 Das Marienburger Tresslerbuch, pp. 75, 308.

${ }^{207}$ Ibid., p. 308. 
various times were Johann Rogge ${ }^{208}$ and Birghayn. ${ }^{209}$ Johann is mentioned most frequently. ${ }^{210}$ We can assume that the person with the status of the grand master's doctor was also the personal doctor of the head of the Order, but he also treated other patients. ${ }^{211}$ The opinions of historians about which doctors in the times of Konrad von Jungingen were the doctor of the grand master vary slightly. It is stated that the doctors of the grand master had been Johann, Bartholomew of Boreszewo, but Niclus Birghayn is not mentioned. ${ }^{212}$ In the opinion of Michalina Broda, the personal physician of Konrad von Jungingen was Johann Rogge and his 'successor' Niclus Birghayn. ${ }^{213}$ According to her, Johann Rogge was the doctor of the grand master in $1400-1405 .{ }^{214}$ In addition to other sources, she relies on the data of the expenditures book of the Order's treasurer. Nevertheless, the status of Johann in 1400-1401 is not fully clear. In the expenditures book of the Order's treasurer, Johann is named the doctor of the grand master magister Johannnes des meisters arzt ${ }^{215}$ only from 1402; until then he was called simply a doctor, magistro Johanni dem arzte. ${ }^{216}$ On the other hand, the annual salary for the year $1400^{217}$ paid to him in 1401 was what he received when he was appointed doctor of the grand master (more about this later). So whether he was the doctor of the grand master in 1400-1401, but this was not recorded in the source mentioned, remains unclear. According to Broda, Niclas Birghayn cared for the health of Konrad

208 Ibid., pp. 140-141, 177-178, 182, 199, 240, 252, 277, 283-284, 287, 288, 298, 310, 316, 342, 366, 378, 538. M. Broda, Lekarze w Państwie Zakonu Krzyżackiego, pp. 55-62, 131, 188; Probst, Der Deutsche Orden, p. 162.

${ }^{209}$ Ibid., pp. 338, 365-366, 380-381, 383, 387, 393-394, 418, 419.

210 Das Marienburger Tresslerbuch, pp. 64, 71, 81-82, 96, 110, 122-123, 140-141, 177-178, 182, 199, 240, 252, 277, 283-284, 287-288, 298, 310, 316, $342,366,378,538$.

${ }^{211}$ Ibid., pp. 283-284, 310; Broda, 'Bartłomej z Boreszewa', p. 35.

212 G. Cuny, 'Die beiden Preußenfahrten Herzog Heinrichs des Reichen von Bayern und Bartholomäus Boreschau', Zeitschrift des Westpreussischen Geschichtsvereins, 59 (1919), p. 145; Świeżawski, 'Bartłomiej z Boreszewa', pp. 371-373.

${ }^{213}$ His successor was a doctor from Gdańsk called Nikolaus Birghayn, see Broda, 'Medical doctors', pp. 11-12.

214 Ibid., p. 12; Broda, Lekarze w Państwie Zakonu Krzyżackiego, pp. 57.

${ }^{215}$ Das Marienburger Tresslerbuch, p. 140.

216 Ibid., pp. 64, 71, 81-82, 96, 110, 122-123.

${ }^{217}$ Meister Johannes der arcz: zum irsten $30 \mathrm{~m}$.; das gelt entpfing her selben von uns am obirsten tage und der meister his uns ym das gelt selbir geben und ist das gelt, das ym gebort vom 1400. jare, wen her im 1400. yare keyn gelt hatte genomen, ibid., p. 96. 
von Jungingen in $1406 .{ }^{218} \mathrm{He}$ appears in the expenditures book of the Teutonic Order from $1405 .^{219}$ But only once in 1406, and in one entry in 1407 , is he called the doctor of the grand master. ${ }^{220}$ Researchers interpret the status of Bartholomew from Boreszawo differently. It is claimed that he was the personal doctor of Konrad von Jungingen ${ }^{221}$ and that the grand master himself invited him in 1398. ${ }^{222}$ However, we have to note that Cuny and Świeżawski did not use data from the expenditures book of the Order's treasurer. Broda says that when the health of the grand master deteriorated, one more physician was hired, Bartholomew of Boreszewo. She also indicates that already in February 1406, Bartholomew treated Konrad von Jungingen, but does not name him as the doctor of the grand master. ${ }^{223}$ Bartholomeo appears from 1399 in the expenditures book of the Teutonic Order's treasurer. The entries of the funds allocated to him show that he travelled much, but the purpose of these trips is not specified; moreover, the activities of Bartholomeo as a doctor are not reflected in them. ${ }^{224}$ From 1406, he appears next to Niclus Birghayn, and his activity can be attributed not only to the medical profession in general, but to an involvement in one way or another with the treatment of the grand master. ${ }^{225}$ An entry in the expenditures book of the Order's treasurer in 1407 indicates that Bartholomew was taking care of the health not only of the grand

${ }^{218}$ Broda, 'Medical doctors', p. 12.

219 Das Marienburger Tresslerbuch, pp. 338, 365-366, 380-381, 383, 387, 393-394, 418-419.

${ }^{220}$ Ibid., p. 381; tem 15 m. magistro Nicolao Birghayn des meisters arzt gegeben vor sien jorlon, als her von hove zoch, ibid., p. 419.

${ }^{221}$ Świeżawski, 'Bartłomiej z Boreszewa', pp. 371-373; G. Cuny, Die beiden Preußenfahrten Herzog Heinrichs, p. 145; Probst, Der Deutsche Orden, pp. 162; Čapaite, 'Sprawy zdrowia i chorób', p. 54. This claim of mine can be adjusted and discussed, because the entries in the expenditures book of the Order's treasurer do not show that in the times of Konrad von Jungingen Bartholomew of Boreszewo had the status of doctor of the grand master.

222 Świeżawski, 'Bartłomiej z Boreszewa', p. 371.

${ }^{223}$ Broda, 'Medical doctors', p. 12; eadem, 'Bartłomej z Boreszewa', p. 35; eadem, Lekarze w Państwie Zakonu Krzyżackiego, pp. 59-61.

${ }^{224}$ Das Marienburger Tresslerbuch, p. 38. For example, in the entry for 15-18 December 1403, it is specified that item $6 \mathrm{~m}$. vor 2 pferde, die meister Bartholomeus hindir ym lis, als her ken Crowcaw gesandt was, ibid., p. 278.

225 item 41/2 m. meister Birchayn vor apoteke unsem homeister, als yn meister Bartholomeus ken Danczk dornoch sante, und vor syn ungelt, ibid., pp. 383; see also: idem, 416, 425, 430; Broda, 'Bartłomej z Boreszewa', p. 34. 
master, but also of other officials of the Order. ${ }^{226}$ However, until 1408 he is not called the doctor of the grand master, or a doctor generally. It is written meister Bartholomeus. ${ }^{227}$ In 1408, he is named as the doctor of the grand master. ${ }^{228}$ So we can assume that in 1406 Bartholomew was not yet the doctor of the grand master (as noted in 1406, Birghayn is named the doctor of the grand master), and in 1407 his status is quite uncertain. It is also important that until 1408 he was not paid the annual salary of a doctor (or at least it is not fixed in the expenditures book of the Order's treasurer), only the remuneration for the treatment of one or another patient is stated. ${ }^{229}$ Attention should be drawn to one more point. In a letter of 29 January 1407, the marshal of the Order told Konrad von Jungingen about Bartholomew's visit and talk with him. According to the official, Bartholomew presented his views on the treatment of the grand master (more later), and offered his services. ${ }^{230}$ So, we believe that if Bartholomew offered his services, it means that at that time he was not the doctor of the grand master, or a doctor with influence over his treatment. Bartholomew's services were used. Here it must be emphasised that he possibly was the doctor who took care of the grand master in the last days of his life. In an entry of the Order's treasurer's ledger made between 12-16 April 1407, after the death of Konrad von Jungingen, Bartholomew is described as the doctor who cared for the grand master, and it is specified that he was paid eight marks for the work: Item $8 \mathrm{~m}$. meister Bartholomeen gegeben von des groskompthurs geheise vor das, als her zu unserm homeister seliger gedechtnisse abe und zu zoch. ${ }^{231}$ According to the expenditures book of the Order's treasurer, Ulrich von Jungingen awarded Bartholomew the status of the grand master's doctor after the death of Konrad von Jungingen. He was the doctor of Grand Master Ulrich von Jungingen. However, at the

226 item $10 \mathrm{~m} .4$ scot dem apoteker Nicolao vom Elbinge vor apoteke unserm homeister dem treszeler dem kornmeister und Kunczen Czipplyn des meisters dyner, als meister Bartholomeus vor sie alsampt geschreben hatte, Das Marienburger Tresslerbuch, p. 416.

${ }^{227}$ Ibid., pp. 416, 425, 430, 514, 528, 542, 547.

228 Ibid., p. 476.

${ }^{229}$ Ibid., pp. 425, 430.

${ }^{230}$ Do sprach her wedir uns, wie das sin rat were, das euwir erwirdikeit io in czit dor ane rates pflege, went es sorglich were, wo man das lisse obirhaut nemen, und her meint, was her euch do czu kunde gutes geraten, des sulde im nicht czu vil sin und welde das thun mit willen, CEV, no. 359, p. 141.

${ }^{231}$ Das Marienburger Tresslerbuch, p. 425. 
same time, it may be assumed that unofficially, that is, even before his status as the doctor of the grand master was confirmed, he was interpreted as such already in 1407, when he cared for Konrad von Jungingen. This consideration is based on an entry of 1408 in the expenditures book of the Order's treasurer. In it, Bartholomew is called the grand master's doctor (Homeisters arzt); however, according to the annual salary paid to him for the year 1407, we can assume that that status was granted to him in 1407, perhaps in view of his work in caring for Konrad von Jungingen ${ }^{232}$. Here we should note that in 1408 and later he was called meyster Bartholomeus, ${ }^{233}$ sometimes magistro, ${ }^{234}$ meyster Bartholomeus arzt or Magister Bartholomeus arzt. ${ }^{235}$ In the entries of 1407-1409 about the funds for him, often his activity as a doctor is not stated. ${ }^{236}$ However, in the expenditures book of the Order's treasurer, on 22 April 1409 it is recorded that Bartholomew was paid half the annual salary of a doctor, i.e. 35 marks. ${ }^{237}$

Some historians link Bartholomew of Boreszewo, the dean of the diocese of Warmia, with intelligence activities; they make the assumption that in the period prior to the Battle of Grünwald, he was a secret agent of the King of Poland. ${ }^{238}$ In the opinion of Sławomir Jóźwiak, who analysed the intelligence and counter-intelligence of the Order, there is no direct proof, confirmed by unambiguous

232 Ibid., p. 476; Broda, 'Bartłomej z Boreszewa', p. 35.

233 Das Marienburger Tresslerbuch, pp. 498, 514, 561.

234 Ibid., pp. 478, 547, 563.

235 Ibid., pp. 528, 542.

236 Ibid., pp. 478, 498, 561, 563.

${ }^{237}$ Magister Bartholomeus arzt: item $35 \mathrm{~m}$. magistro Bartholomeo syn lon of eyn halb jor, das im of ostern geboret im 1409. jore; das gelt antwerte im unser schryber an sinte Jorgen obende. item $35 \mathrm{~m}$. meyster Bartholomeo syn jorlon volne; das gelt enpfing [her] von uns am frytage vor Symonis Jude, ibid., p. 528.

238 J. Voigt, Geschichte Preussens von den ältesten Zeiten, pp. 114-115, footnote 1; Cuny, Die beiden Preußenfahrten Herzog Heinrichs, pp. 146-152, Beilage no. 2, pp. 160-161; A. Czacharowski, 'Opozycja rycerstwa ziemi chełmińskiej w dobie Grunwaldu', W kręgu stanowych i kulturalnych przeobrażeń Europy Pótnocnej w XIV-XVIII wieku, ed. Z.H. Nowak (Torun, 1988), p. 83 (Čapaitè, 'Sprawy zdrowia i chorób', p. 37, note 6 inaccurate information is provided: the general scope of the article of A. Czacharowski is specified, and not the place of the text relevant to the analysed theme); Świeżawski, 'Bartłomiej z Boreszewa', pp. 372-379 (in the article Čapaite, 'Sprawy zdrowia i chorób', p. 37, note 6, information is provided inaccurately: the general scope of the article of Świeżawski is specified, and not the place of the text topical to the analysed theme); S.M. Kuczyński, Wielka wojna z Zakonem K rzyżackim w latach 1409-1411 (Warsaw, 1980), pp. 111-112. 
sources, confirming these assumptions. ${ }^{239}$ However, the researcher states that the details of Bartholomew's activities during the period of the war are not absolutely clear, and he could have been on the side of the Polish king. ${ }^{240}$ Bearing this in mind, we can raise these questions: did Bartholomew have doubts about the treatment of the grand master only as a doctor? Or maybe it was competition between doctors? If Bartholomew was a secret agent of the King of Poland, he might have had other motives. His goal may have been to enter the immediate circle of the grand master. We do not currently have answers to these questions. We should note that Bartholomew also treated Čuurna, the marshal of the estate of Vytautas, ${ }^{241}$ who probably suffered from some kind of internal disease.

When high-ranking officials were ill, then doctors would travel to them, or the officials themselves would travel for treatment. It is unclear whether they travelled for treatment to a specific doctor, or to a certain place for the possibility of better treatment. For instance, in 1407, Čupurna, the marshal of the estate of Vytautas, was treated for a while at Elbing. The expenses for Čupurna's treatment and his trip home are entered in the expenditures book of the Order's treasurer. ${ }^{242}$ A year later, the doctor Bothen from the Order travelled to him. An entry in the treasurer's book of expenditures on 17 October 1408 testifies to this. Two marks were allocated for the doctor's trip. ${ }^{243}$ According to Petrauskas, this was the grand master's physician Bartholomew. ${ }^{244}$ However, this claim is debatable. The researcher dates the visit of the doctor to 1397 , but at that time Bartholomew

239 S. Jóźwiak, K. Kwiatkowski, A. Szweda, S. Szybkowski, Wojna Polski $i$ Litwy z Zakonem krzyżackim w latach 1409-1411 (Molbork, 2000), pp. 545, 615; S. Jóźwiak, Wywiad i kontrwywiad w państwie zakonu krzyżackiego w Prusach (Malbork, 2004), s. 109; S. Jóźwiak, 'Polscy i litewscy szpiedzy w Malborku w pierwszych dziesięcioleciach XV wieku', Zapiski Historyczne, 69 (2004), z. 4, p. 32.

${ }^{240}$ Jóźwiak, Kwiatkowski, Szweda, Szybkowski, Wojna Polski i Litwy z Zakonem krzyżackim, pp. 545, 615.

${ }^{241}$ Das Marienburger Tresslerbuch, pp. 430.

242 ...dis nochgeschreben gelt hat der huskompthur von Konigisberg vor unsern homeyster of rechenschaft usgegeben, angehaben am tage Dyonisii im 1407. jore: zum irsten 8 schot dem furmanne, der her Cschapornen wyn und ander gerete furte ken der Frauwenburg, als her wedir heym wolde zyhen noch der krangheyt, gegeben am sontage noch Jacobi. item 7 scot vor spyselegel becher tonnen und ander gevese, do her Cchaporne ine tat, was her bedorfte, als her noch der krangheyt wedir heym zoch, Das Marienburger Tresslerbuch, p. 442; CEV, p. 970; Petrauskas, 'Tolima bičiulyste', p. 217.

243 item $2 \mathrm{~m}$. meyster Bothen zerunge, als her zu her Czapornen zoch, Das Marienburger Tresslerbuch, p. 504; CEV, Appendix, p. 970.

${ }^{244}$ Petrauskas, 'Der Frieden im Zeitalter', p. 34; idem, 'Tolima bičiulyste’', p. 217. 
was not yet the grand master's doctor. ${ }^{245}$ What is important is that in the book of expenditures of the Order's treasurer, it is recorded that he was meyster Bothen. ${ }^{246}$ The researcher did not provide arguments supported by sources confirming the claim that Bartholomew, the doctor of the grand master, and meyster Bothen are the same person. In debating this, attention should be directed to one detail: in the entries of the expenditures book of the Order's treasurer in 1399-1409, the doctor Bartholomew all the time is called meister Bartholomeus, magister Bartholomeus. ${ }^{247}$

Not only high-ranking officials of the Grand Duchy of Lithuania received medical treatment in the Order. In the expenditures book of the Order's treasurer, it is entered that in 1404, ten marks were given to the baker of Vytautas travelling to an eye doctor in Torun. ${ }^{248}$

In the correspondence of Grand Duke Vytautas and his adressees, there are very few direct and indirect news items according to which we can decide whether the treatment was successful or not. In 1407, the Brandenburg komtur Markward von Salzbach, the envoy of the Order, in a letter to the chief marshal of the Order, informed him that, on the subject of the poor health of Čupurna, the marshal of Vytautas' court, the doctors indicated that they doubted they could help him. ${ }^{249}$ The long illness of his wife Julijona emphasised by Vytautas and the request to send her the best possible internal medicine doctor ${ }^{250}$ lets us believe that until then she was not treated very successfully. In contrast, the visit of the doctor Heinrich was successful. ${ }^{251}$ There is no doubt that the success of the treatment was determined by: what disease it was, the general state of the patient's health, and the methods of treatment.

In the sources analysed, there are only a few hints. For example, in the expenditures book of the Order's treasurer, on 10 June 1400, there are two entries on the subject. In one of them, it is marked: Item $15 \mathrm{~m}$. dem arzte, der den convents hochemeister

${ }^{245}$ For the dating of the events, see note 48.

246 Das Marienburger Tresslerbuch, p. 504.

${ }^{247}$ Ibid., pp. 38, 248, 383, 416, 425, 476, 478, 498, 514, 528, 542, 547, 561, 563.

${ }^{248}$ Item $10 \mathrm{~m}$. Niclus Wytowtes becker gegeben zerunge ken Thorun zum augenarzte, Das Marienburger Tresslerbuch, p. 321.

${ }^{249}$ GStAPK, OBA, no. 928; $C E V$, no. 367 , pp. 147-148.

250 Ibid., no. 1213 , p. 714.

${ }^{251}$ Ibid., no. 1216, p. 716; Prochaska, Ostatnie lata Witolda, pp. 60, 62. 
gesneten hat zum Elbinge, geben am donrstage noch pfingsten, und $1 \mathrm{~m}$. synen knechten, die $y m$ holften. ${ }^{252}$ In the entry it is not specified what kind of specialisation the doctor had. Nevertheless, we can assume that he was an internal medicine doctor (as is mentioned in this article, the named arzt is associated with an internal medicine doctor). He worked with assistants. I was unable to determine what treatment was applied. According to the entry, it is hypothetically debatable whether it could have been some kind of surgical intervention. According to the second entry for the same day: Item $4 \mathrm{~m}$. dem convents kochemeister zerunge geben, alzo her zum Elbinge lag, do her sich lis snyden, am donrstage noch pfingisten. ${ }^{253}$

The treatment of Grand Master Konrad von Jungingen, and the search for doctors, found an echo in the correspondence. The Order's marshal, in a letter on 29 January 1407, told the grand master about his conversation with master Bartholomew about his (the grand master's) disease. The official said that Bartholomew expressed his doubts about the treatment for the grand master. ${ }^{254}$ The letter indicates discussions about the methods of the treatment of Konrad von Jungingen. The official was aware of and mentioned in the letter some of the details linked with the treatment or illness of the grand master. ${ }^{255}$ The marshal of the Order advised Konrad von Jungingen, and asked him for some time to take Bartholomew and use the services of both doctors (i.e. probably the doctor that was treating him until then and Bartholomew). According to the official, it would not harm the grand master if for some time both doctors treated him, because one could possibly know what was useful for the illness of the head of the Order that the other did not know. In the letter, the marshal stated:

so wellen wir euch raten und bitten euwir erwirdikeit, das ir meister Bartholomews, och uff eine czit euch nemet. Was mochte euwir erwirdikeit schaden, das die beide

${ }^{252}$ Das Marienburger Tresslerbuch, p. 75.

253 Ibid., p. 75.

${ }^{254}$ Do sprach her wedir uns, wie das sin rat were, das euwir erwirdigkeit io in czit dor ane rates pflege, CEV, no. 359, p. 141.

255 Also begunden wir mit im czu reden von euwir crankheit und legten im vor, als von dem bluten do wir im dovon eigentlich gesait hatten, ibid., no. 359, p. 141. Čapaite, 'Sprawy zdrowia i chorób', p. 58, note 181, in the citation there is a typographical error, the words do wir im. are omitted; Broda, 'Bartłomej z Boreszewa', p. 34. 
etliche czit bi euch weren. Der eine mochte villichte das wissen, das euch nucze und fromelich czu euwir krankheit were, des der andere nicht enwoste. ${ }^{256}$

There is a lot of information about money for medicines in the expenditures book of the Order's treasurer. ${ }^{257}$ Sometimes in the entries it is only indicated that drugs were purchased, and the amount allocated for them. Often it is indicated at the instruction of which doctor, for which patient or patients the medicines were bought, and how much they cost. ${ }^{258}$ For example, according to the entry of 12 July 1404, medicines were bought for Grand Duchess Ona. The doctor Johann also participated in the procurement:

item $12 \mathrm{~m} .2$ scot vor apoteke unserm homeister dem alden und nuwen groskompthur und Wytouwtynnen und sust zwen Růszen; das gelt his magister Johannes der arzt geben am tage Margarethe. ${ }^{259}$

This allows us to make the assumption that in 1404 the grand duchess was ill, but in the analysed correspondence of that time, we do not find any hints about this. Of course, it may be that the letters did not survive, they disappeared, but it may be that the purchase of medicines for Ona was coordinated through messengers or reliable persons. The role of Johann also remains unclear, e.g. he or someone else decided what medicines had to be bought for the duchess. Here it should be noted that the grand duchess is called Wytouwtynnen. That is the form of personal name used showing the woman's family status according to the husband.

Travelling to a congress in Kaunas in 1408, the grand master, in addition to the abundant provisions (food, wine, spices, etc), was also carrrying medicines. Along with him also travelled his personal physician Bartholomew. The medicines were purchased from a pharmacist in Elbing. ${ }^{260}$ Other sources mention a purchase

$256 C E V$, no. 359, p. 141; Čapaite, 'Sprawy zdrowia i chorób', p. 55: raten should be ratten; och eine czit euch nemen should be och uff eine czit euch nemet; etliche zit should be czit; enwaste should be enwoste.

257 Das Marienburger Tresslerbuch, pp. 24, 32, 40, 59, 71, 85, 98, 110, 122 , 140, 225, 267, 283-284, 308, 316, 351, 353, 366, 383, 393-394, 400, 416, 418, $430,441$.

258 Ibid., pp. 40, 85, 110, 122, 177-178, 225, 267, 284, 310, 316, 366, 380, 383, 393-394, 400, 416, 418, 426, 441; Broda, Lekarze w Państwie Zakonu Krzyżackiego, pp. 57-60, 73, 79, 131.

259 Eadem, p. 310; eadem, 'Medical doctors', p. 14.

260 apoteker $12 \mathrm{~m}$. 16 scot 3 den: item $1 \mathrm{~m}$. 13 scot dem apoteker vor 2 eppel unserm homeyster und vor ander apteke. item $5 \mathrm{~m}$. 2 scot vor apteke, dy meyster Bartholomeus mete nam of den tag zu Cauwen. item $2 \mathrm{~m}$. 5 scot minus 1 sol vor apteke Pauwel unsers homeysters underkemerer. [...] 151/2 scot den kranken herren 
only once. ${ }^{261}$ According to the entry of 26 July 1402, two times were purchased for the grand master:

Item 5 m. 2 scot dem selben apoteker vor kruide dem groskompthur wedir zu machen, als die kriode ym vortrang, do her in die reyse zoch, an der mitwochen noch Jacobi ap. noch des groskompthurs briefes usweisunge. ${ }^{262}$

The same was purchased in 1404 , but now for the grand master: item 11/2 m. vor kride us der apoteke, die magister Johannes der arzt koufte unserm homeister. ${ }^{263}$ For example, according to the entry of 1 July 1409 there was purchased:

item 2 m. 22 scot vor 10 pfunt sal armonyacum, das pfunt vor 7 scot, magistro Bartholomeo. item 7 scot vor 1 steyn alune magistro Bartholomeo. item 15 scot minus 10 den. vor dy glas und das dorzu gehoret ouch magistro Bartholomeo. item $1 / 2$ m., dy magister Bartholomeus vorzeret hat. ${ }^{264}$

Sometimes we can assume that medicines made to order were purchased. For example, in the entry of the expenditures book of the Order's treasurer, it is stated on 27 December:

item 16 $1 \frac{1}{2}$ m. 2 scot vor apoteke, die meister Johannes der arzt his geben dem apoteker vom Elbinge, die her in 11/2 yare unserm homeister und groskompthur gemacht hatte, die alles meister Johannes von ym nam. ${ }^{265}$

However, we are unable to explain from the analysed sources how often and in what circumstances the medicines were made.

Remuneration given to the doctors is not mentioned in the letters of Vytautas and his adressees. Asking to send his wife a doctor of internal medicine, Vytautas informed Russdorf that the doctor should come to Grodno, where an escost assigned by the grand duke would wait for him. Vytautas ensured that the doctor would be supplied with horses and everything he needed. The escort would accompany him to the residence of the grand duke. ${ }^{266}$ There is a

in der furmaria vor apteke. das gelt enpfing Nicolaus der apoteker vom Elbinge am obende Nicolai, Das Marienburger Tresslerbuch, p. 514.

${ }^{261}$ Ibid., pp. 178, 316, 351, 547.

262 Ibid., p. 178.

${ }^{263}$ Ibid., p. 316.

${ }^{264}$ Ibid., p. 547.

265 Ibid., p. 284.

266 Und ist sache, das ir sulchen werdet mogen habin und czu uns senden, so wellet in ken Garthen egedocht usrichten, do wellen wir bestellen und uff in lossen warten, wenn her dohen qweme, das her do geleiczlute finde, die im pferde von danne und ander nottorft uff dem wege schafen und in do, do wir uff die czeit werden sein, sullen brengen, CEV, no. 1213, p. 714; Čapaite,, 'Sprawy zdrowia i chorób', p. 55: in losen warten, wenn her dohen quemen should be lossen warten, 
lot of data about the payments to doctors in the expenditure ledger of the Order's treasurer. For example, in the expenditures book of the Order's treasurer, it is recorded that three marks were given to the eye doctor sent in 1400 by the grand master to Vytautas. ${ }^{267}$ It is not known whether Vytautas also paid the doctor. The entries in the expenditures book of the Order's treasurer indicate that the doctors received an annual salary. The annual salary of the doctor Johann (identified from 1402 as the grand master's doctor) in 1401-1405 was 30 marks. ${ }^{268}$ In 1406 an annual salary of 20 marks was paid to the doctor of the grand master Birghayn. ${ }^{269}$ Bartholomew, the doctor of Grand Master Ulrich von Jungingen, received a significantly greater annual salary, it was 70 marks. According to the entry of the expenditures book of the Teutonic Order's treasurer on 8 April 1408, we can say that Ulrich von Jungingen allocated a new (higher) annual salary to Bartholomew. The treasurer added:

Homeisters arzt: Man sal wissen, das man meister Bartholomeen jerlich $70 \mathrm{~m}$. geben sal of zwene tage, als $35 \mathrm{~m}$. of ostern und of wynachten. suscepit $35 \mathrm{~m}$. am donrstage vor palmen noch vom 1407. jare. item 35 m. meyster Bartholomeen, dy her enpfing am tage Lucie virginis. ${ }^{270}$

In addition to the annual salary, the doctors also received a reward for the treatment of a patient. Entries in the expenditures book of the Order's treasurer show that the amounts were very varied. It is difficult to say what determined the size of the reward: the qualifications of the doctor, the length of treatment, the severity of the disease, or other factors. For example, the expenditures book records that in 1407, 60 marks were paid to Master Bartholomew for the treatment of Čupurna, the marshal of Vytautas' court. ${ }^{271}$ The same year, five marks were paid to the surgeon for the treatment

wenn her dohen qweme; uff dem wege schaffen und indo should be uff dem wege schafen und in do.

${ }^{267}$ Item $3 \mathrm{~m}$. deme ogenarczte, den der meister zu herzoge Wytowdt gesandt hatte, am tage annuncciacionis Marie, Das Marienburger Tresslerbuch, p. 70.

${ }^{268}$ Ibid., pp. 96, 141, 199, 283, 298, 342; Broda, 'Medical doctors', pp. 12, 14.

${ }^{269}$ Item $20 \mathrm{~m}$. meister Birghayn des meisters arzte gegeben vor syn yorlon. Das gelt nam her selben am sonabunde noch Katherine, Das Marienburger Tresslerbuch, p. 381.

${ }^{270}$ Ibid., p. 476.

${ }^{271}$ Item 60 m. meyster Bartholomeen, das her her Czapornen gearztyet hatte, gegeben am dinstage noch assumpcionis Marie, ibid., p. 430. 
of the grand master and the kellirmeister. ${ }^{272}$ In the expenditures book of the Teutonic Order's treasurer, it is entered that between 28 and 29 December 1405, the grand master gave his physician Johann a horse costing eight marks: item $8 \mathrm{~m}$. vor eyn pferdt, das unser homeister magistro Johani syme arzte gab. ${ }^{273}$ Whether this was a gift from the grand master to the doctor, bearing in mind that from 1406 Johann was no longer the doctor of the grand master, remains unclear.

\section{Author Details}

Rūta Čapaite is a graduate of the Pedagogical University of Vilnius. Working at the Lithuanian Institute of History's Department of the History of the Grand Duchy of Lithuania. Her area of research is Latin paleography. She also analyzes the development of Gothic and humanistic italics in the chanceries of the GDL in the 15 th -17 th centuries. Her other interests are mediaeval epistolary culture and correspondence as a means of communication and administration in the mileu of Vytautas the Great.

Address: Department of the History of the GDL, Lithuanian Institute of History, Kražiu g. 5, 01108 Vilnius, Lithuania

Email: capaite@hotmail.com

\section{SVEIKATOS TEMA LIETUVOS DIDŽIOJO KUNIGAIKŠČIO VYTAUTO IR JO AMŽININKŲ LAIŠKUOSE}

\section{Santrauka}

$R \overline{U T A} \check{C} A P A I T \dot{E}$

Straipsnyje aptariamos Lietuvos didžiojo kunigaikščio Vytauto, jo adresatų ir adresantų laiškuose aptinkamos su sveikatos reikalais susijusios žinios. Svarstomi šie klausimai: apie kieno sveikatą (turima omenyje asmens rangas) ir kodèl rašyta? Kokios žinios ir kokia forma buvo pateikiamos (pvz., kaip apibūdintos ligos ar jų požymiai)? Ar yra laiškuose tiesiogiai su gydymu susijusios informacijos? Korespondencijoje aptinkamos žinios yra papildytos Vokiečių ordino iždininko išlaidų knygos ir Lenkijos karaliaus Jogailos dvaro sąskaitų duomenimis bei kronikų pasakojimais.

272 item $5 \mathrm{~m}$. Wachsmut dem wundarzte gegeben, das her unserm homeister seliger gedechtnisse und des meisters kellirmeister gearzteyet hatte, Das Marienburger Tresslerbuch, p. 425.

${ }^{273}$ Ibid., p. 378. 
Lietuvos didžiojo kunigaikščio Vytauto, jo adresatų ir adresantų laiškuose, be vyraujančių politinių aktualijų, rašyta apie savo ir artimiausios aplinkos asmenų sveikatą (pvz., ligą, išgijimą ir t.t.), domètasi kitų valstybių valdovų ar aukšto rango pareigūnų sveikatos būkle. Retai sveikatos temai skirdavo visą laišką, dažniausiai informacija apie tai įsiterpdavo daugiatemiuose laiškuose. Korespondencijoje aptinkamą informaciją sveikatos klausimais pagal pobūdị galima sugrupuoti ì dalykinę, dalykinę-asmeninę ir asmeninę.

Iš Vytauto ir jo korespondentų minimų negalavimų požymių beveik neịmanoma nustatyti, kokiomis ligomis sirgta. Išvardyti gerai matomi, daugeliui susirgimų būdingi simptomai (pvz., vidinis karštis, apetito stoka, kojų silpnumas) arba minèta bloga bendra savijauta. Labai retai rašyta apie sveikimo požymius. Šiek tiek informacijos apie buvusius susirgimus suteikia didžiajam magistrui adresuoti Vytauto ir Jogailos prašymai atsiųsti kurios nors specializacijos gydytoją bei įrašai Vokiečių ordino iždininko išlaidų knygoje apie gydytojų vizitus. Tačiau ir tais atvejais nepaaiškèja, kokias ligas gydytojai gydè.

Pagal analizuotus šaltinius išskirtinos trys susirgimų grupės: akių, kojų ir vidaus ligos. Kokios buvo akių ar kojų ligos, nustatyti nepavyko. Kojų problemos sietinos su įvairiomis traumomis ir veikiausiai vidaus ligomis. Nepavyko nustatyti, kokiomis vidaus ligomis sirgta. $\mathrm{Su}$ vidaus ligomis siejami šie laiškuose minimi simptomai: vidinis karštis, apetito stoka, silpnos kojos, netrumpas sirgimas, ilgai besitęsianti permaininga sveikatos būklè.

Korespondencijoje ir Ordino iždininko išlaidų knygoje minimi trijų specializacijų gydytojai - akių (ogenarzt), žaizdų arba chirurgas (wundarzt), ir vidaus ligų (leiparczt). Daroma prielaida, kad Ordino iždininko išlaidų knygoje gydytojais (arzt) vadinami asmenys buvo vidaus ligų gydytojai.

Nagrinètuose šaltiniuose beveik neužsimenama apie gydymo būdus. Vytauto ir jo korespondentų laiškuose taip pat nekalbama apie atlygi gydytojams, bet Ordino iždininko išlaidų knygos įrašai rodo, kad gydytojas gaudavo metinę algą ir atlygi už kurio nors asmens gydymą. Liko neaišku, kas lèmè atlygio dydi - gydymo laikas, ligos sunkumas ar kitos priežastys. 